\title{
Upotreba SVAR analize pri utvrđivanju učinaka fiskalnih šokova u Hrvatskoj
}

Ravnik, Rafael; Žilić, Ivan

Source / Izvornik: Odabrani prijevodi, 2011, 2, 1 - 28

Journal article, Published version

Rad u časopisu, Objavljena verzija rada (izdavačev PDF)

https://doi.org/10.3326/op.8

Permanent link / Trajna poveznica: https://urn.nsk.hr/urn:nbn:hr:242:046328

Rights / Prava: Attribution-NonCommercial-NoDerivatives 4.0 International/ImenovanjeNekomercijalno-Bez prerada 4.0 međunarodna

Download date / Datum preuzimanja: 2023-04-26

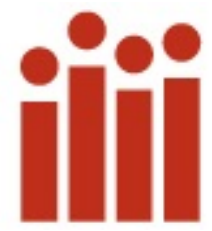

Institute of Public Finance Repository

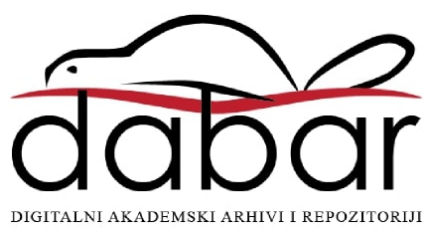




\section{UPOTREBA SVAR ANALIZE PRI UTVRĐIVANJU UČINAKA FISKALNIH ŠOKOVA U HRVATSKOJ}

Smičiklasova 2I

Io ooo Zagreb

Tel. oI / 4886-444, 4819-363

Fax OI/4819-365

ured@ijf.hr

www.ijf.hr

\section{ODABRANI \\ PRIJEVODI}

ISSN I847-7445

\section{BR. 8/II}

citirati: Ravnik R. i Žilić, I., 20II. "The use of SVAR analysis in determining the effects of fiscal shocks in Croatia". Financial Theory and Practice, 35 (I), 25-58.

http://www.ijf.hr/eng/FTP/2OII/I/ ravnik-zilic.pdf

Svi Odabrani prijevodi dostupni su na: http:/ / www.ijf.hr/index.php?ime=268

\author{
Rafael RAVNIK \\ Hrvatska narodna banka, Zagreb \\ rafael.ravnik@hnb.hr \\ Ivan ŽILIĆ* \\ zilicivan@gmail.com
}

\author{
Izvorni znanstveni članak ${ }^{* *}$ \\ JEL: E62, H3O, H5O \\ UDK: 336.I \\ DOI: $10.3326 /$ op. 8
}

\section{Sažetak}

U radu se koristi multivarijantna Blanchard-Perotti SVAR metodologija za analizu kratkoročnih učinaka dezagregirane fiskalne politike na ekonomsku aktivnost, inflaciju i kratkoročnu kamatnu stopu. Rezultati upućuju na to da su učinci šoka državnih izdataka i šoka državnih prihoda relativno najveći za kamatnu stopu, a najmanji za inflaciju. Porezni šok u kratkom roku povećava stopu inflacije te ujedno smanjuje kratkoročnu kamatnu stopu, a nakon godinu dana dolazi do stabilizacije na početnoj razini, dok šok izdataka dovodi do obrnutog efekta. Efekti fiskalne politike na proxy varijablu dohotka tj. industrijsku proizvodnju su manje ekonomski intuitivni. Naime, šok izdataka smanjuje, a šok prihoda trajno povećava industrijsku proizvodnju. Na temelju rezultata empirijske analize prikazano je da šok poreza ima permanentni utjecaj na buduću sumu poreza, dok buduće razine državne potrošnje nisu povezane sa današnjim šokovima rashoda. Također je ispitan međusobni utjecaj komponenti fiskalne politike te je zaključeno da šok prihoda trajno povećava rashode, dok šok rashoda značajno ne utječe na prihode, što je u skladu s tendencijom rasta javnog duga. Nadalje, utvrđeno je da šokovi prihoda i rashoda nemaju zrcalni efekt čime je dezagregirana analiza fiskalnih utjecaja opravdana.

Ključne riječi: SVAR model, fiskalni šokovi, proračunski prihodi, proračunski rashodi

\footnotetext{
* Autori zahvaljuju dvojici anonimnih recenzenata na korisnim komentarima i sugestijama te prof. dr. sc. Ivi Bićaniću na motivaciji, podršci i sveukupnom trudu. Stavovi izneseni u ovome radu stavovi su autora.

${ }^{* *}$ Primljeno: I. lipnja 2010.

Prihvaćeno: 16. studenog 2010.
} 


\section{Uvod}

Tematika vezana uz utjecaj fiskalnih šokova na ekonomsku aktivnost se ponovo vraća u središte istraživačkih interesa nakon osnivanja Europske monetarne unije gdje državama članicama fiskalna politika postaje ključni instrument provođenja ekonomske politike. Iz tog je razloga upravo početkom ovog stoljeća značajno porastao broj istraživanja vezanih uz ekonomske posljedice šokova državnih prihoda i rashoda.

U ovom radu bit će prikazani dinamički efekti fiskalnih šokova ${ }^{\mathrm{I}}$ na ekonomsku aktivnost, razinu cijena i kratkoročnu kamatnu stopu u Hrvatskoj. Ekonometrijska metoda korištena u ovom istraživanju je strukturalni vektorski autoregresijski (SVAR) model, čija je primjena na fiskalne šokove započela radom Blanchard i Perotti (I999). No, taj se rad odnosi na SAD, ali ubrzo nakon toga slijede istraživanja koja se odnose na europske zemlje, kao što je Heppke-Falk, Tenhofen i Wolf (2006) za Njemačku, de Castro i de Cos (2006) za Španjolsku, Giordano, et al. (2008) za Italiju i sl.

Zaključci o djelovanju šokova državnih izdataka i poreznih šokova na ekonomsku aktivnost iz svih navedenih radova različiti su za različite zemlje i različite metodološke pristupe (Kamps i Caldara, 2008). Također se razlikuju i varijable koje su korištene u navedenim istraživanjima. U ovom radu će biti korištene varijable po uzoru na Perotti (2002), a predstavljaju minimalni skup makroekonomskih varijabli potrebnih za ispitivanje dinamičkih efekata fiskalne politike.

Što se Hrvatske tiče, makroekonomske posljedice fiskalnih šokova ispitana su $u$ dva istraživanja (Benazić, 2006. i Rukelj, 2009), koja koriste srodnu, strukturnu VEC metodologiju uz nešto drukčije varijable, dok pristup Blancharda i Perottija još nije korišten. Također nisu odgovorena pitanja kakve posljedice imaju fiskalni šokovi na razinu cijena i kamatnu stopu. Upravo se ovim radom želi ispitati kakve će rezultate dati istraživanje, koristeći standardni pristup razvijen u Perotti (2002). Usporedit će se rezultati šokova na kretanje gospodarske aktivnosti, a ponudit će se i odgovor na pitanje o posljedicama šoka na cijene. Bit će pokazane i posljedice na kratkoročne kamatne stope, a na primjeru svih varijabli bit će uspoređen kratkoročni i srednjoročni efekt. Fiskalni šokovi su dezagregirani na dvije komponente: šokove prihoda i rashoda, pa će se ispitati razlike među posljedicama navedenih šokova, međusobni utjecaj šokova ova dva instrumenta, ali i intenzitet te vrijeme trajanja posljedica fiskalnih šokova. Osim toga, rezultati strukturnog VAR model bit će uspoređeni sa onima dobivenim rekurzivnim VAR modelom.

Glavni cilj rada je, dakle, ispitati implikacije dezagregiranih instrumenata fiskalne politike, te prikazati u kojoj je mjeri moguće utjecati na poslovne cikluse. Empirijska analiza ponuditi će odgovore na temeljna pitanja ovog istraživanja, koje se odnose na smjer, intenzitet i trajanje makroekonomskih posljedica dezagregiranih fiskalnih šokova.

U sljedećem dijelu rada prikazana je literatura vezana uz fiskalne šokove, zajedno sa osnovnim zaključcima. Nakon toga je ukratko objašnjena korištena ekonometrijska metodologija te je identificiran strukturni model zajedno s poretkom varijabli rekurzivnog VAR modela. Prije konačnih

${ }^{\mathrm{I}}$ Šok je definiran u specifikaciji Blanchard-Perotti metode. 
rezultata su ukratko objašnjeni korišteni podaci. Osim rezultata u obliku funkcija impulsnog odaziva i dekompozicije varijanci, učinjen je i test stabilnosti modela, nakon čega slijedi zaključak.

\section{Pregled literature}

Osim već spomenutih istraživanja vezanih za Europu i SAD, SVAR metoda se primjenjuje i na ostale zemlje. Ovdje su nabrojani samo neki od tih radova: Perotti (2002) te de Arcangelis i Lamartina (2003) za zemlje OECD-a općenito, Lozano i Rodriquez (2008) za Kolumbiju, de Plesis, Smit i Struzenegger (2007) za Južnoafričku Republiku. Svim istraživanjima je zajednička metoda, odnosno SVAR, a razlikuju se djelomično u korištenim varijablama. Izvorni model u Blanchard i Perotti (1999) sastoji se od samo tri varijable: proračunski prihodi, rashodi i realni BDP. Perotti (2002) proširuje taj model dodajući kratkoročnu kamatnu stopu i razinu cijena.

Uz standardne SVAR modele, u empirijskim istraživanjima primjenjuje se još četiri pristupa u analizi fiskalnih šokova, a to su: (I) Bayesian strukturni VAR modeli (vidjeti npr. Afonso i Sousa, 20oga i 20ogb), (2) tzv. Mountford-Uhlig pristup kod kojeg se postavljaju ograničenja na predznak parametara (Mountford i Uhlig, 2005), (3) fiskalni dummy pristup kojeg su razvili Ramey i Shapiro (1998) te (4) rekurzivni postupak koristeći dekompoziciju Choleskog (vidjeti npr. Fatas i Mihov, 200Ia i 200Ib; te Favero; 2002). Kamps i Caldara (2006. i 2008) uspoređuju ove pristupe i zaključuju da rekurzivnim postupkom uz pravilnu specifikaciju redoslijeda varijabli u modelu dolazimo do gotovo identičnih zaključaka kao i uz korištenje uobičajenih strukturnih VAR modela, dok je odstupanje rezultata najveće primjenom fiskalnog dummy pristupa. Osim navedenih pet pristupa prikazivanja fiskalnih šokova, primjenjuju se i strukturni vektorski modeli korekcije pogrešaka (SVECM), kao npr. Krušec (2003) na primjeru zemalja Europske monetarne unije ili Benazić (2006) i Rukelj (2009) na primjeru Hrvatske, dok su Gali, Lopez-Salidoz i Valles (2007) razvili New Keynesian model pomoću kojeg simuliraju fiskalne šokove.

Kao što smo već u uvodnom dijelu spomenuli, rezultati iz navedenih radova se djelomično razlikuju među zemljama i ne postoje jednoznačni odgovori makroekonomskih varijabli na fiskalne šokove. Što se tiče investicija može se zaključiti da prevladavaju neoklasični rezultati, tj. autori zaključuju da povećanje izdataka, barem djelomično, dovodi do istiskivanja investicija. Na primjeru pet OECD zemalja Perotti (2002) zaključuje da postoji samo neznatan utjecaj državnih izdataka na ekonomsku aktivnost. Heppke-Falk, Tenhofen i Wolf (2006) dolaze do gotovo jednakih rezultata na primjeru Njemačke u kratkom roku, uz naglasak da se navedeni pozitivni efekt $\mathrm{u}$ dugom roku pretvara $\mathrm{u}$ negativan. De Arcangelis i Lamartina (2003), kao i Perotti (2002), dokazuju statistički signifikantan pozitivan efekt državnih izdataka na ekonomsku aktivnost u kratkome roku. Kao što je već rečeno, intenzitet i duljina trajanja makroekonomskih posljedica šokova izdataka nisu jednaki za sve zemlje, ali općenito se može zaključiti da su oni pozitivni u kratkom roku, dok je dugoročno taj efekt različit. ${ }^{2}$ Utjecaj poreza na ekonomsku aktivnost je većinom negativan, dok u kratkom roku postoje znatna odstupanja od tog pravila. Tako primjerice Lozano i Rodriquez (2008) za Kolumbiju te Heppke-Falk,

\footnotetext{
${ }^{2}$ Vidjeti rezultate i komparativne analize u Kamps i Caldara (2006. i 2008).
} 
Tenhofen i Wolf (2006) za Njemačku prikazuju pozitivan efekt poreznog šoka na BDP-a, a de Castro i de Cos (2006) zaključuju da samo u vrlo kratkom roku (prva dva kvartala), postoji pozitivan efekt na BDP Španjolske, dok je srednjoročni efekt, kao što i nalaže Keynesijanska teorija, negativan. Rezultat je vrlo sličan onim dobivenima iz dinamičkih stohastičkih modela opće ravnoteže kao što je npr. New Keynesian model u radu Gali, Lopez-Salidoz i Valles (2007) u kojem je dodatno dokazan i porast zaposlenosti kao posljedica povećanja državnih izdataka. Efekt povećanja izdataka i poreza na razinu cijena pokazuju nešto veće razlike i nema jednoznačnog odgovora koji bi vrijedio za sve zemlje pa se postavlja pitanje kakvi će rezultati biti za Hrvatsku.

Od dosadašnjih istraživanja o utjecaju fiskalnih šokova na hrvatsku ekonomiju valja izdvojiti rezultate iz Benazić (2006), koji dolazi do zaključka da povećanje proračunskih prihoda dovodi do usporavanja gospodarske aktivnosti, dok povećanje izdataka dovodi do porasta BDP-a, a važno je i spomenuti da je znatno jači dugoročni efekt poreza od efekta izdataka. No kao što je već rečeno, autor koristi ekonometrijsku metodu SVECM, dok će u ovome radu biti korišten strukturni VAR model. Jedino recentnije istraživanje o fiskalnoj politici koje je usko vezano uz temu našeg rada je Rukelj (2009), koji ispituje interakciju monetarne i fiskalne politike, također koristeći SVEC model, a uključuje sljedeće varijable: indeks ekonomske aktivnosti (zbroj različitih ponderiranih pokazatelja ekonomske aktivnosti), novčanu masu te državne izdatke. Autor zaključuje da ekspanzivne politike uistinu dovode do ekonomske ekspanzije i da ti efekti vrijede i u dužem roku, ali također upozorava da rezultati nisu sasvim pouzdani. Osim toga pokazuje da se fiskalna i monetarna politika kreću u suprotnom smjeru tj. da su ove politike supstituti. Rezultati će biti uspoređeni sa rezultatima ovog istraživanja, tj. strukturnog VAR modela koji ne uključuje monetarnu politiku, ali sa druge strane je učinjena podjela fiskalnih šokova na porezne šokove i šokove izdataka te je dodatno uključena razina cijena, a ispitan je i utjecaj na kratkoročnu kamatnu stopu, što je i predloženo u Rukelj (2009).

Istraživanjem o cikličnosti fiskalne politike u Hrvatskoj došlo se do zaključka da u posljednjih nekoliko godina prevladava prociklična i restriktivna fiskalna politika (Švaljek, Vizek i Mervar, 20o9), ali se nisu ispitale ekonomske posljedice fiskalne politike. Rezultati navedenog rada o elastičnostima pojedinih poreza na poreznu bazu bit će korišteni u identifikaciji našeg SVAR modela. Sopek (2009) ispituje posljedice financijske krize na deficit, ali i javni dug te zaključuje da do 20I3. godine javni dug ostaje unutar maastrichtskog kriterija od 6o\%.

Iz svega navedenog može se zaključiti da je ovim radom potrebno odgovoriti na otvorena pitanja iz prethodnih istraživanja, vezana uz ovu tematiku te s nešto izmijenjenom specifikacijom modela i korištenom ekonometrijskom metodom usporediti rezultate o posljedicama fiskalne politike. Kao što je već ranije rečeno, to će biti učinjeno korištenjem peterodimenzionalnog strukturalnog VAR modela, što je i uobičajena praksa prikazivanja takvih šokova. 


\section{Metodologija}

U ovome će dijelu ukratko biti objašnjena ekonometrijska metoda koja se koristi, zatim BlanchardPerotti model kojim se identificira sustav, način računanja egzogenih elastičnosti potrebnih za model, podaci koji se koriste $\mathrm{u}$ analizi te VAR model koji impulsne funkcije procjenjuje rekurzivnim postupkom. Svrha usporedbe dvaju načina identifikacije jest da se rezultati benchmark SVAR pristupa stave u komparaciju u s drugim metodologijama.

\section{I. Strukturalna vektorska autoregresija}

Modeli strukturalne vektorske autoregresije (SVAR) koriste ograničenja koje nameće ekonomska teorija kako bi identificirali sustav, tj. iz reduciranih šokova dobili strukturne i ekonomski interpretativne funkcije impulsnog odaziva (Impulse response function, IRF). Kako SVAR metodologija nije zastupljena u empirijskim istraživanjima u Hrvatskoj, slijedi kratki prikaz načina identifikacije SVAR modela korišten u ovom radu, koji se temelji na identifikaciji predloženoj u Blanchard i Perotti (I999).

VAR modeli su od početka osamdesetih godina prošlog stoljeća standardni alat empirijske analize makroekonomista. Jednostavni su za uporabu, često su uspješniji u prognozama od složenih simultanih modela (Bahovec i Erjavec, 2009) i apriori su nerestriktivni, tj. ne nameću „nevjerojatne identifikacijske restrikcije“(često korištena Simsova sintagma (Enders, 2003)).

Stoga, za početak razmotrimo strukturni oblik VAR modela reda p (Bahovec i Erjavec, 2009)3:

$$
A E_{t}-A_{0}+C(L) Z_{t-1}+e_{t}
$$

gdje je $Z_{t} k$ - dimenzionalni vektor endogenih varijabli u vremenu $t, Z_{t-1} k$ - dimenzionalni vektor endogenih pomaknutih varijabli, $e_{t} k$ - dimenzionalni vektor strukturnih inovacija $e_{t} \sim\left(\mathrm{o}, \Sigma_{\theta}\right), A_{0} k-$ dimenzionalni vektor konstantnih članova, dok je $A$ matrica strukturalnih koeficijenata dimenzije $k \times k$, a $C(L)$ polinom operatora pomaka L reda p. Prema Gottschalk (200I) postoji infinitivan skup različitih vrijednosti matrica $A$ i $\mathcal{C}(\boldsymbol{L})$ za dane podatke i te je parametre nemoguće identificirati jer različiti strukturni oblici daju iste reducirane oblike VAR-a ${ }^{4}$. Stoga je nemoguće donijeti zaključke o pravom stanju (strukturalnom modelu) iz reduciranog oblika bez identificirajućih restrikcija. Upravo je i cilj SVAR metodologije pretpostavljanje identificirajućih restrikcija koje se temelje na ekonomskoj teoriji. Strukturni se oblik VAR-a može raspisati u reduciranom obliku kao:

$$
Z_{t}=v+D(E) Z_{t-1}+u_{t}
$$

gdje je $v=A^{-1} A_{Q}, D(L)=A^{-1} C(L)$, te $u_{t}=A^{-1} \Theta_{t}$, tj. reducirani oblik inovacija (šokova) koji nemaju izravnu ekonomsku interpretaciju, $u_{\varepsilon} \sim\left(0, \Sigma_{w}\right)$. Reducirani oblik VAR-a može se procijeniti standardnom OLS (Ordinary Least Squares) metodom procjene, jer je takav procjenitelj nepristran i

\footnotetext{
${ }^{3}$ Notacija iz Bahovec, Erjavec (2009) je promijenjena da bude u skladu s Lütkepohl (2005) i s McCoy (I997).

${ }^{4}$ Vidjeti primjer u Gottschalk (200I).
} 
asimptotski efikasan (Enders, 2003). Kako je iz reduciranog nemoguće dobiti strukturni oblik, funkcije impulsnog odaziva (IRF), tj. dinamički odgovori endogenih varijabli na jedinični šok neke od varijabli u sustavu nemaju smislenu ekonomsku interpretaciju, jer je $u_{t}$ reducirani oblik inovacija koje nemaju izravni ekonomski kontekst već su linearna kombinacija strukturnih inovacija. Također, kako $\Sigma_{w} I_{E Z}$ (jedinična matrica reda k), tj. $u_{k t}$ su najčešće korelirane u vremenu $t$, nije jednostavno interpretirati jedinične šokove neke varijable kad je taj šok povezan $u$ vremenu $t$ s šokom neke druge varijable (Bahovec i Erjavec, 2009). Da bi se iz reduciranog dobio strukturni oblik, koriste se podaci izvan uzorka, tj. egzogena ograničenja. Elementi matrice A poznati su ukoliko je poznat trenutan odnos strukturnih i reduciranih inovacija, a kako je $e_{i}=A u_{i}$, moguće je dobiti informacije o strukturnim inovacijama. Ovakav model naziva se A model SVAR-a (Lütkepohl, 2005). Važno je naglasiti da ograničenja odnosa među parametrima vrijede samo za početni period, a kasnije se efekt prenosi kroz VAR ovisno o specifikaciji. Također, moguće je i ortogonalizirati matricu varijanci i kovarijanci reduciranih šokova $\Sigma_{u}$, i to na način da se pretpostavi da je $u_{t}$ linearna kombinacija $e_{\tau} \sim\left(0_{r} I_{R}\right)$, pa je $u_{\tau}=B \varepsilon_{\tau}$, a $\sum_{m}=B \sum_{p} B^{\prime}$. Kako je matrica varijanci i kovarijanci strukturnih inovacija jedinična, tj. $e_{k t}$ su nekorelirane u vremenu $t$ moguće je pronaći matricu $B$ za koji vrijedi $\Sigma_{\mathrm{s}}=B B^{l}$. Ovakav model naziva se B model SVAR-a (Lütkepohl, 2005). Problem sa bilo kojom ortogonalizacijom jest da ne postoji „najbolja“ ortogonalizacija koja će jedinstveno dekomponirati matricu varijanci i kovarijanci reduciranog oblika inovacija (Bahovec i Erjavec, 2009). Standardna dekompozicija, koja omogućuje interpretativne funkcije impulsnog odaziva, je faktorizacija Choleskog, u kojoj je $\Sigma_{\mathrm{\alpha}}=G G^{5}$, gdje je $G$ donje trokutasta matrica (sve vrijednosti iznad glavne dijagonale su nule). Očito je da je poredak endogenih varijabli u VAR modelu bitan jer se poretkom implicitno određuje struktura povezanosti inovacijas. Upravo je to i glavni prigovor navedene faktorizacije, jer iako se smatra ateoretskom, ona pretpostavlja strukturu povezanosti inovacija koja je teško u skladu s ekonomskom teorijom (Keating, 1992). Postoji k! načina da se poredaju endogene varijable (McCoy, 1997), a poredak je irelevantan ukoliko ne postoji korelacija između reduciranog oblika varijabli (Enders, 2003). SVAR metodologija, koja se koristi u ovom radu, ali i u svim radovima koji istražuju efekte fiskalne politike, je $\mathrm{AB}$ model u kojem je $A u_{\longleftarrow}=B \Theta_{t}$, i u koji je potrebno pretpostaviti $2 k^{2}-\frac{1}{2} k(k+1)$ ograničenja da bi sustav bio točno identificiran (Lütkepohl, 2005). Iz navedenih je modela identifikacije vidljivo da je SVAR metodologija zapravo analiza šokova (McCoy, 1997).

Korisno je iznijeti i povezanost analize šokova i standardne AR reprezentacije koju pojašnjava Gottschalk (200I). Polazišni oblik je jednadžba (I), tj. strukturni oblik VAR-a u kojem $\epsilon_{v} \approx\left(\mathrm{C}_{k} I_{k}\right)$. Ukoliko se od svake strane jednadžbe (I) oduzme uvjetno očekivanje vektora endogenih varijabli, gdje se kao uvjet pretpostavlja da su poznate informacije o endogenim varijablama do trenutka $t$, tj. $E_{t-1} Z_{t}$, s lijeve će se strane dobiti $A u_{t}$ jer je to, prema jednadžbi (2), razlika $Z_{t}$ i $D(L) Z_{t-1}$ (izraza

\footnotetext{
${ }^{5}$ Vidjeti primjer u Bahovec i Erjavec (2009).
} 
koji sumira podatke o $Z_{\tau}$ u vremenu $\left.t-1\right)$, ako se zanemari vektor konstantnih članova. S desne se strane jednadžbe (I) izraz $C(L) Z_{t-1}$ eliminira, jer sadrži samo varijable koje su poznate do vremena $t-1$, pa ostaje samo ako se opet zanemari vektor konstantnih članova, vektor strukturnih inovacija $e_{t}$. Ovim razlikovanjem očekivanih i neočekivanih promjena u endogenim varijablama iz strukturnog oblika VAR-a, dobiva se A model SVAR-a, a jednako bi se mogli dobiti i B i AB model.

\subsection{Specifikacija Blanchard-Perotti metodologije identifikacije}

Slijedi prikaz korištenog SVAR modela i identifikacije sustava u svrhu dobivanja ekonomski interpretativnih funkcija impulsnih odaziva. Dakle, procijenjen je reducirani oblik VAR modela iz jednadžbe (2), gdje je $Z_{t}=\left[g, y_{v}, \pi_{v}, p, r\right]$ ' vektor endogenih varijabli, koji sadrži desezonirane i logaritmirane rashode državnog proračuna $g$, desezoniranu i logaritmiranu industrijsku proizvodnju y kao proxy varijablu dohotka u baznim indeksima (baza=2005), logaritmirane stope promjene indeksa potrošačkih cijena $\pi$, prihode državnog proračuna $p$, desezonirane i logaritmirane te prekonoćnu kamatnu stopu na novčanom tržištu $r$. Broj pomaka $p$ odabran je po Akaike informacijskom kriteriju i LM testu te iznosi 5 pomaka. Nakon što se reducirani oblik VAR-a procjeni OLS metodom, potrebno je, kako je već objašnjeno egzogeno pretpostaviti koeficijente kako bi se iz reduciranih inovacija dobile strukturne koje imaju smislenu ekonomsku interpretaciju. Blanchard i Perotti (1999) razvijaju metodologiju strukturne identifikacije koja se temelji na institucionalnim uvjetima poreznog sustava. Glavna je ideja da ukoliko se uzme dovoljno visoka frekvencija podataka (navedeni autori uzimaju kvartalne podatke), sistematske diskrecijske reakcije nositelja fiskalne politike neće biti zbog sporog sakupljanja podataka, ali i spore provedbe diskrecijskih mjera. Kako u našem modelu koristimo mjesečne podatke, navedeni je argument još dodatno naglašen. Iako se strukturni VAR-ovi dominantno koriste $\mathrm{u}$ analizama monetarne politike, diskretni karakter prikupljanja i objavljivanja fiskalnih varijabli, naspram kontinuiranog karaktera objavljivanja monetarnih varijabli, čini analizu fiskalne politike pogodnijom za ovu identifikacijsku metodu.

Prema Perotti (2002), reducirani oblici inovacija državne potrošnje $\left(u_{\varepsilon}^{q}\right)$ i poreznih prihoda $\left(u_{t}^{p}\right)$ smatraju se linearnim kombinacijama triju komponenata: (I) automatske reakcije državne potrošnje i poreznih prihoda na inovacije dohotka $\left(u_{\tau}^{y}\right)$, inflacije $\left(u_{\tau}^{\pi}\right)$ i kamatne stope $\left(u_{\tau}^{r}\right)$; (2) sistematske diskrecijske reakcije nositelja ekonomske politike na inovacije dohotka, inflacije i kamatne stope; (3) slučajnih diskrecijskih šokova tj. strukturnog oblika inovacija državne potrošnje $\left(e_{\tau}^{g}\right)$ i poreznih prihoda $\left(e_{z}^{p}\right)$. Dakle, reducirani oblici inovacija državne potrošnje i poreznih prihoda izgledaju formalno:

$$
\begin{aligned}
& u_{\tau}^{g}=\alpha_{y}^{g} u_{t}^{y}+\alpha_{\pi}^{g} u_{t}^{\pi}+\alpha_{r}^{g} u_{t}^{r}+\beta_{p}^{g} \theta_{t}^{\gamma}+\beta_{g}^{g} \theta_{t}^{g}
\end{aligned}
$$

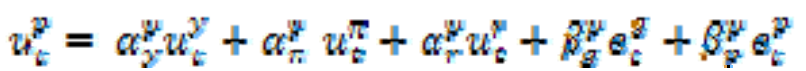


Početna pretpostavka da država ne može reagirati u istom kvartalu tj. mjesecu na šokove ostalih varijabli dolazi do izražaja, jer koeficijenti $\alpha_{k}^{j}$ odražavaju isključivo automatske reakcije državne potrošnje i poreznih prihoda na varijable dohotka, inflacije i kamatne stope, dok $\beta_{k}^{\jmath}$ prikazuju trenutan učinak $k$-tog strukturnog šoka na $j$-tu varijablu. Kako su $e_{\varepsilon}^{p}$ i $e_{\varepsilon}^{g}$ povezani reduciranim oblikom inovacija, ne mogu se dobiti OLS metodom (Heppke-Falk, Tenhofen i Wolff, 2006). Reducirani se oblici inovacija državne potrošnje i poreznih prihoda mogu prikazati u formi ciklički prilagođenih reduciranih inovacija:

$$
\begin{aligned}
& u_{t}^{g, G A}=u_{t}^{g}-\left(\alpha_{y}^{g} u_{t}^{y}+\alpha_{\pi}^{g} u_{t}^{\pi}+\alpha_{r}^{g} u_{t}^{r}\right)=\beta_{g}^{g} \theta_{t}^{p}+\beta_{g}^{g} \theta_{t}^{g} \\
& u_{t}^{p, C A}=u_{t}^{p}-\left(\alpha_{y}^{p} u_{t}^{y}+\alpha_{\pi}^{p} u_{t}^{\pi}+\alpha_{r}^{p} u_{t}^{r}\right)=\beta_{g}^{p} e_{t}^{g}+\beta_{p}^{p} a_{t}^{p}
\end{aligned}
$$

Slijedeći je korak u procesu identifikacije donijeti zaključke o poretku fiskalnih varijabli. Ukoliko se pretpostavi da odluke vezane za državnu potrošnju prethode odlukama vezanim za porezne prihode, tada je $\beta_{\%}^{Q}=0$, a ukoliko se pretpostavi obratno, vrijedi $\beta_{g}^{p}=0$. Iako Perotti (2002) tvrdi da ni za jedno, ni za drugo ne postoji teoretska ili empirijska podloga, čini se ipak smislenijim pretpostaviti da odluke o državnoj potrošnji diktiraju odluke o državnim prihodima pa pretpostavljamo da je $\beta_{\%}^{g}=0$. Iako je navedeno ograničenje pretpostavljeno i u Perotti (2002), Heppke-Falk, Tenhofen i Wolff (2006), Kamps i Caldara (2006), de Castro i de Cos (2006) te u Lozano i Rodriquez (2008), bit će testirana i suprotna pretpostavka.

Uz početnu pretpostavku da je $\beta_{p}^{g}=0$, ciklički prilagođeni reducirani šokovi izgledaju:

$$
\begin{gathered}
u_{t}^{g, C A}=\beta_{g}^{g} e_{t}^{g} \\
u_{\tau}^{p, C A}=\beta_{g}^{p} e_{t}^{g}+\beta_{p}^{p} e_{t}^{p}
\end{gathered}
$$

Ostale jednadžbe reduciranih oblika inovacija procjenjuju se pomoću instrumentalnih varijabli, gdje se kao instrumenti koriste $z_{t}$, jer su ortogonalni (Heppke-Falk, Tenhofen i Wolff, 2006). Također, procedura dobivanja ostalih jednadžbi vidljiva je i u Perotti (2002), a one izgledaju:

$$
\begin{gathered}
u_{t}^{y}=\alpha_{g}^{y} u_{t}^{g}+\alpha_{p}^{y} u_{t}^{p}+p_{y}^{y} e_{t}^{y} \\
u_{t}^{\pi}=\alpha_{g}^{\pi} u_{t}^{g}+a_{y}^{\pi} u_{t}^{y}+a_{g}^{\pi} u_{t}^{y}+\beta_{\pi}^{\pi} \mathrm{e}_{t}^{\pi} \\
u_{t}^{r}=\alpha_{g}^{r} u_{t}^{g}+\alpha_{y}^{r} u_{t}^{y}+\alpha_{\pi}^{r} u_{t}^{\pi}+\alpha_{p}^{r} u_{t}^{y}+\beta_{r}^{m} e_{t}^{r}
\end{gathered}
$$

Kao što je već spomenuto, SVAR model koji se koristi u analizi fiskalnih šokova naziva se AB model (Lütkepohl, 2005), koji izgleda ovako:

$$
A u_{t}=B e_{t}
$$

pa je moguće konstruirati matrice A i B: 


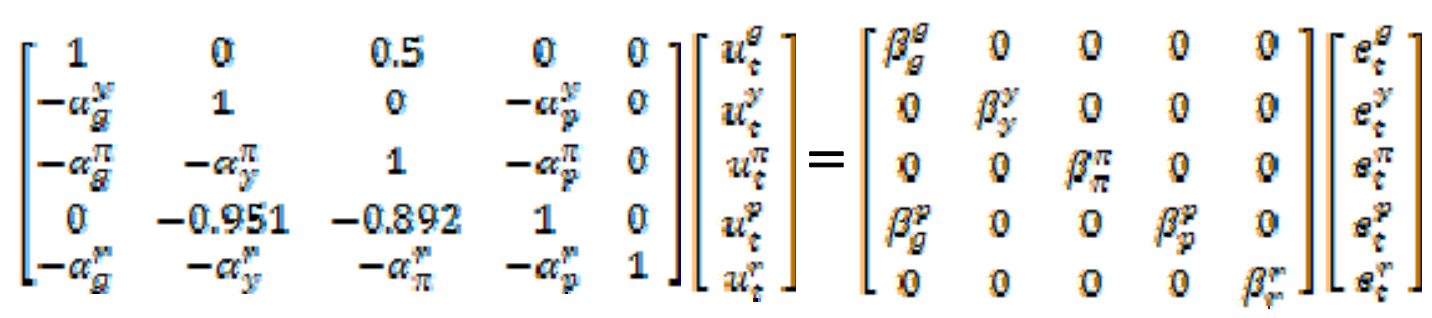

Da bi sustav bio točno identificiran, treba pretpostaviti $2 k^{2}-\frac{1}{2} k(k+1)$, tj. 35 ograničenja ( $k$ je broj endogenih varijabli) ukupno u obje matrice. B matrica ima 19 koeficijenta koji su jednaki nuli, a glavna dijagonala A matrice nudi još 5 ograničenja. Svi koeficijenti vezani uz jednadžbu reducirane inovacije državne potrošnje su nula, osim utjecaja inflacije na reducirane inovacije državne potrošnje koji se pretpostavlja da je -o.5, jer se rashodi za plaće državnih službenika, koji čine značajan udio državne potrošnje, ne indeksiraju u istome periodu na inflaciju. Ovakav odnos inflacije i državne potrošnje preuzet je iz Kamps i Caldara (2006), Lozano i Rodriquez (2008) te Štikova (2006). Svi su ostali koeficijenti vezani uz reducirane inovacije državne potrošnje nula, jer je državna potrošnja u potpunosti pod kontrolom ekonomske politike, koja ne može reagirati unutar istog perioda, a automatskog efekta nema, jer se radi o varijabli čija je dinamika isključivo pod utjecajem odluka države. Iz navedenog argumenta proizlaze 4 dodatne restrikcije. Nadalje, pretpostavka je da reducirana inovacija prekonoćne kamatne stope ne utječe niti na jednu od preostalih četiriju reduciranih inovacija, što daje još 3 restrikcije. Kako je utjecaj državnih rashoda na porezne prihode moguće modelirati u matrici B sa strukturnim inovacijama, u matricu A se za taj odnos pretpostavlja da je nula te se također pretpostavlja da reducirani oblik inovacija inflacije ne utječe u istom periodu na reducirani oblik dohotka, što daje još dvije restrikcije. Preostale dvije restrikcije koje su potrebne da se točno identificira sustav, dobivaju se izračunom utjecaja reduciranih inovacija dohotka na reducirane inovacije poreza (egzogena elastičnost o.95) te utjecajem reduciranih inovacija inflacije na reducirane inovacije poreza (egzogena elastičnost o.89), metodologijom koja je objašnjena u nastavku. Ovakva metodologija točne identifikacije SVAR-a primijenjena je i u Lozano i Rodriquez (2008), Štikova (2006), te Kamps i Caldara (2008).

Potrebno je naglasiti neke činjenice vezane uz prirodu fiskalnih šokova čije utjecaje promatramo. Šokovi $e_{t}^{p}$ i $e_{t}^{g}$ predstavljaju jednokratno povećanje prihoda odnosno rashoda za jednu standardnu devijaciju u odnosu na prosjek promatranog razdoblja. Perotti (2002) naglašava da iako se može tvrditi da zbog prirode proračunskog procesa postoji samo jedan šok fiskalne politike godišnje, u praksi fiskalne vlasti, brojnim rebalansima, kao i promjenama politike oporezivanja, često mijenjaju tok fiskalne politike. Bernanke i Mihov (1996) diskutirajući o monetarnim šokovima, naglašavaju činjenicu više tehničkog karaktera. Naime, kako se fiskalni šok ne može promatrati u kontekstu varijabla koje su u modelu (a u našem modelu, osim fiskalnih varijabli radi se o dohotku, inflaciji i kratkoročnoj kamatnoj stopi), šok fiskalnih varijabli ne može se interpretirati kroz inicijalno kretanje tih varijabli. Navedeni autori objašnjavaju uzroke šokova ${ }^{6}$ : (i) nesavršene informacije fiskalnih vlasti o trenutnom stanju ekonomije, (ii) promjene u relativnim ponderima koje fiskalne vlasti stavljaju na razne oblike

${ }^{6}$ Prilagođeno, jer autori iznose uzroke monetarnih šokova. 
proračunske potrošnje. Prvi uzrok jest i eksplicitno pretpostavljen u identifikaciji modela, dok se drugi objašnjava činjenicom da je proces donošenja odluka o državnoj potrošnji uvelike pod utjecajima borbe za što veće državne izdatke nekoj interesnoj ili socijalnoj skupini pa se ponderi raznih oblika državne potrošnje mijenjaju.

\subsection{Egzogene elastičnosti}

Kako bismo izveli potrebne egzogene elastičnosti, primijenili smo metodu opisanu u Blanchard i Perotti (1999), Perotti (2002), Kamps i Caldara (2006. i 2008), kao i u de Castro i de Cos (2006) te Lozano i Rodriquez (2008). Izračun elastičnosti proračunskih prihoda u odnosu na dohodak sastoji se od izračuna elastičnosti poreznih komponenti u odnosu na njihovu baze te elastičnosti svake baze u odnosu na dohodak. Elastičnosti poreznih komponenti u odnosu na bazu preuzeti su iz Švaljek, Vizek i Mervar (2009)7 , izračunati prema metodi Bouthevillain et al. (200I), dok su ostale elastičnosti direktno izračunate prema istoj metodi iz kvartalnih podataka mjesečnika Ministarstva financija $\mathrm{RH}$ i Državnog zavoda za statistiku za razdoblje od 200I. do kraja 2009. godine. Korišteni su kvartalni podaci zbog neobjavljivanja učestalije frekvencije osobne potrošnje koja nam služi kao baza za nekoliko proračunskih prihoda, a bez koje ne bi bilo moguće izračunati potrebne egzogene elastičnosti.

Jedinstvena elastičnost poreza u odnosu na dohodak izračunata je prema sljedećoj formuli:

$$
\alpha_{y}^{p}=\sum_{i=1}^{n} s_{E_{i}}^{p_{i}} \times a_{y}^{s_{l}} \times \frac{T_{t}}{T}
$$

gdje $a_{B_{i}}^{z} t$ predstavlja elastičnost $l$-tog poreza u odnosu na $i$-tu bazu, $a_{y t}^{B_{t}}$ predstavlja elastičnost $i$-te baze u odnosu na dohodak, dok $T_{i} / \mathrm{T}$ predstavlja ponder $i$-tog poreza u sumi korištenih poreza, $F^{\prime}=\sum_{i=1}^{n} F_{t}^{\prime}$.

U ovom slučaju korišteno je pet najvećih prihoda državnog proračuna: porez na dohodak, porez na dobit, socijalni doprinosi te dva indirektna poreza; porez na dodanu vrijednost i trošarine. Baza porezu na dohodak i socijalnim doprinosima je masa plaća, baza porezu na dobit je bruto operativni višak $^{8}$, dok je baza indirektnim porezima osobna potrošnja privatnog sektora. Kao što je već rečeno, $T=\sum_{i=1}^{n} T_{i}$ je suma pet korištenih prihoda, pa je $T_{i} / \mathrm{T}$ u ovome slučaju jednostavan ponder svakog prihoda u tom zbroju, s kojim se množe elastičnosti prihoda u odnosu na bazu i baze u odnosu na dohodak, kako bi se dobila jedinstvena elastičnost $a_{y}^{\%}$. Navedeni udjeli su dobiveni iz prosječnih udjela pojedinih poreza kao i u Heppke-Falk, Tenhofen i Wolf (2006), dok su vrijednosti $s_{s_{i}}^{\nabla l} \mathrm{i} s_{y}^{D_{i}}$ izračunate prema metodologiji objašnjenoj u Lozano i Rodriques (2008). Prikaz svih elastičnosti dan je u tablici I gdje možemo vidjeti da jednadžbom (I4) dolazimo do elastičnosti poreza u odnosu na dohodak od o.95.

\footnotetext{
${ }^{7}$ Preuzete su kratkoročne elastičnosti izračunate ekonometrijskom metodom kao što nalaže i de Castro i de Cos (2006).

${ }^{8}$ Izračunat na isti način kao u Švaljek, Vizek i Mervar (2009), tj. od BDP-a je oduzeta masa plaća.
} 
Uspoređujući dobiveni rezultat rezultatima ostalih istraživanja, vidimo da je najsličnija elastičnost dobivena u radu Heppke-Falk, Tenhofen i Wolf (2006) za Njemačku (također približno o.95), dok ona u Perotti (2002) iznosi o.92. Za Španjolsku je izračunata elastičnost od o.62 (de Castro i de Cos, 2006), za SAD I.85, Ujedinjeno Kraljevstvo o.76, Australiju 0.8I, a za Kanadu I.86 (Perotti, 2002). Možemo zaključiti da rezultati za Hrvatsku ne odstupaju znatno od onih u ostalim zemljama.

\section{Tablica I.}

Elastičnost državnih prihoda u odnosu na dohodak

\begin{tabular}{|c|c|c|c|c|}
\hline Prihod: & $a_{B_{i}}^{z}$ & $a_{y}^{E_{1}}$ & $s_{y}^{y_{1}}=s_{y}^{b_{1}} \times a_{B_{1}}^{p_{1}}$ & $\frac{T_{t}}{T}$ \\
\hline Porez na dohodak & 2.32 & 0.88 & 2.05 & 0.07 \\
\hline Porez na dobit & 2.12 & I.O3 & 2.20 & 0.12 \\
\hline $\begin{array}{l}\text { Porez na dodanu } \\
\text { vrijednost }\end{array}$ & I.I3 & 0.79 & 0.89 & 0.35 \\
\hline Trošarine & 0.50 & 0.79 & 0.40 & O.II \\
\hline Socijalni doprinosi & 0.62 & 0.80 & 0.50 & 0.35 \\
\hline
\end{tabular}

Napomena: vrijednosti zaokružene na dvije decimale.

Izvor: Izračun autora te Švaljek, Vizek i Mervar (2009).

Osim dohodovne elastičnosti koristit ćemo i one u odnosu na inflaciju, također prema gore navedenoj metodologiji, uz određene modifikacije. Naime, izračuni ovih elastičnosti se djelomično razlikuju među autorima, a u ovom radu će biti korišten algoritam iz Perotti (2002) te de Castro i de Cos (2006). Zbog proporcionalnosti razine cijena sa indirektnim porezima autori pretpostavljaju da elastičnosti poreza na dobit u odnosu na inflaciju, kao i elastičnosti indirektnih poreza u odnosu na inflaciju iznose o. Ostale vrijednosti su izračunate kao i u slučaju dohotka. To znači da u ovom radu računamo elastičnosti socijalnih izdataka i poreza na dohodak u odnosu na odgovarajuću bazu, a uvrštavamo ih u sljedeću jednadžbu:

$$
\alpha_{\pi}^{p}=\sum_{i=1}^{n} a_{B_{i}}^{p} \times s_{y}^{D_{i}} \times \frac{T_{i}}{T}
$$

Ponovo koristeći međurezultate iz Švaljek, Vizek i Mervar (2009), prema vlastitim izračunom ostalih komponenti ( $g_{\pi}^{B_{i}}=2.35$ gdje je $B_{i}$ masa plaća) te ranije izračunatih pondera dolazimo do vrijednosti $\alpha_{\pi}^{p}$ od o.89. Usporedba dobivene elastičnosti sa onima iz prijašnjih istraživanja ponovo dovodi do zaključka da rezultat ne odstupa od uobičajenih vrijednosti. ${ }^{9}$

Elastičnost državnih izdataka u odnosu na inflaciju $\left(\alpha_{\pi}^{g}\right)$ od -0.5 preuzeta je iz Perotti (2002), jednako kao što je učinjeno i u Kamps i Caldara (2006 i 2008) te Lozano i Rodriquez (2008). Prema Perotti (2002) ova vrijednost mora ležati između o i -I, a on bira upravo -0.5 bez izračuna koji je korišten kod ostalih vrijednosti. Autor ovaj odabir opravdava činjenicom, da je dio državnih izdataka neelastičan u

\footnotetext{
${ }^{9}$ Elastičnosti iz prije spomenutih zemalja se kreću između o,78 i I,25 prema Perotti (2002:43) i de Castro, de Cos (2006:I5).
} 
odnosu na cijene, a dio ima elastičnost od -I iz razloga što je dio izdataka indeksiran u odnosu na CPI (primjerice nadnice $u$ javnom sektoru), dok dio dobara nije indeksiran.

\subsection{Specifikacija rekurzivne metode}

Strukturne se inovacije mogu iz reduciranog oblika dobiti i pomoću faktorizacije Choleskog ${ }^{\text {IO }}$. Navedena faktorizacija pretpostavlja da je B matrica jedinična, a A matrica donje trokutasta (svi elementi iznad glavne dijagonale, koja je jedinična, su nula), čime se pretpostavlja $\Sigma_{w}=A^{-1} \Sigma_{\varepsilon}\left(A^{-1}\right)^{\ell}$ (Lütkepohl, 2005). Poredak varijabli u vektoru endogenih varijabli postaje bitan, jer se drugačijim poretkom implicitno mijenja i struktura povezanosti inovacija. Kako u 5erodimenzionalnom modelu ima I2O različitih poredaka endogenih varijabli postavlja se pitanje kao odabrati optimalan poredak. U praksi se na prvo mjesto stavlja varijabla čiju varijancu budućeg perioda najbolje objašnjava njena strukturna inovacija (što je vidljivo iz dekompozicije varijance), no problem je što svaki poredak implicira drugačiju dekompoziciju varijance, pa je potreban značajan trud da se odredi optimalan poredak (Bahovec i Erjavec, 2009). Stoga je u praksi uobičajenije poredati varijable po vremenskoj dimenziji njihovog nastupanja, tj. varijabla za koju se smatra da će prva nastupiti stavlja se prva u vektor endogenih varijabli. Poredak varijabli u Choleskovoj faktorizaciji preuzet je iz Kamps i Caldara (2008), te izgleda:

$$
\left[\begin{array}{ccccc}
1 & 0 & 0 & 0 & 0 \\
-\alpha_{\partial}^{y} & 1 & 0 & 0 & 0 \\
-\alpha_{g}^{n} & -\alpha_{y}^{n} & 1 & 0 & 0 \\
-\alpha_{g}^{p} & -\alpha_{y}^{p} & -\alpha_{\pi}^{p} & 1 & 0 \\
-\alpha_{g}^{r} & -\alpha_{y}^{r} & -\alpha_{\pi}^{r} & -\alpha_{p}^{r} & 1
\end{array}\right]\left[\begin{array}{c}
u_{t}^{g} \\
u_{t}^{y} \\
u_{t}^{\pi} \\
u_{t}^{p} \\
u_{t}^{r}
\end{array}\right]=\left[\begin{array}{lllll}
1 & 0 & 0 & 0 & 0 \\
0 & 1 & 0 & 0 & 0 \\
0 & 0 & 1 & 0 & 0 \\
0 & 0 & 0 & 1 & 0 \\
0 & 0 & 0 & 0 & 1
\end{array}\right]\left[\begin{array}{c}
e_{t}^{g} \\
e_{t}^{y} \\
\theta_{t}^{\pi} \\
e_{t}^{p} \\
e_{t}^{p}
\end{array}\right]
$$

Ovakvom preidentificirajućom faktorizacijom pretpostavlja se da reducirani šok državne potrošnje nije $u$ istom mjesecu povezan s niti jednim drugim šokom u modelu te također da na reducirani šok industrijske proizvodnje u istom mjesecu utječe samo šok državne potrošnje i tako redom. Bitno je naglasiti da bilo koja faktorizacija definira odnose reduciranih šokova samo u prvom periodu (mjesecu), a da kasnije svi šokovi mogu utjecat na sve. Također vidljivo je da je poredak endogenih varijabli isti kao u SVAR modelu, a kako se A matrice SVAR-a i VAR-a bitno ne razlikuju, neke od nultih ograničenja (pogotovo vezane uz reducirani šok državne potrošnje) mogu se i opravdati s istim argumentima kao i u SVAR modelu, čime ova faktorizacija dobiva i teoretski kontekst. Rezultati dobiveni rekurzivnom metodom prikazani su $u$ dodatku, a komentira ih se $u$ poglavlju empirijski rezultati.

\footnotetext{
${ }^{\text {Io }}$ Vidjeti dio rada koji se odnosi na SVAR metodologiju.
} 


\section{Podaci}

Već je ranije rečeno da će u ovome SVAR modelu biti korišteni sljedeći podaci: prihodi i rashodi državnog proračuna na mjesečnoj razini ${ }^{\text {II }}$ (Ministarstvo financija, 20Io), bazni indeks (baza=2005) industrijske proizvodnje (Državni zavod za statistiku, 20Io), inflacija te kratkoročna kamatna stopa (Hrvatska narodna banka, 20Io). Svi navedeni podaci, osim kamatnih stopa, bit će izraženi u logaritamskom mjerilu, a inflacija je izračunata diferenciranjem logaritma indeksa potrošačkih cijena. Korišteni su mjesečni podaci od oI/200I. do I2/2009, tj. od datuma od kojeg su dostupni podaci indeksa industrijske proizvodnje u statističkim mjesečnicima DZS-a.

Unatoč tome što se u ovom slučaju radi o relativno kratkom razdoblju, od tek devet godina, možemo zaključiti da je Io8 opservacija tehnički dovoljno za procjenu VAR modela, kao primjerice u HeppkeFalk, Tenhofen i Wolf (2006) gdje je korištena serija od I20 kvartalnih opservacija. Ovo je ujedno i razlog korištenja mjesečnih podataka za razliku od uobičajenih kvartalnih u analizi ovakve vrste, jer za Hrvatsku nije dostupna dovoljno duga vremenska serija kvartalnih podataka. Naime, dostupna je serija od tek nešto manje od 50 podataka što bi dovelo do smanjivanja stupnjeva slobode te do nemogućnosti provođenja testa stabilnosti modela. Pravilo korištenja što učestalije frekvencije kako bi se eliminirao utjecaj diskrecijske fiskalne politike (Blanchard i Perotti, I999; te Perotti, 2002) također ide u prilog korištenju mjesečnih podataka. No, pri donošenju zaključaka treba uzeti u obzir činjenicu da dobiveni rezultati funkcije impulsnog odaziva dohotka zapravo prikazuju industrijsku proizvodnju, čija dinamika nije u potpunosti praćena dinamikom kretanja BDP-a. Dodatan nedostatak je nemogućnost prikazivanja dekompozicije dohotka na pojedine komponente, tj. prikazivanje reakcija investicija i osobne potrošnje na fiskalne šokove iz razloga što se ti podaci objavljuju kvartalnom frekvencijom.

U dodatku su prikazane originalne i desezonirane serije prihoda i rashoda državnog proračuna na mjesečnoj razini izražene u logaritmima (LNPRI i LNRAS stoji za originalne, a LNPRI_SA i LNRAS_SA za desezonirane vrijednosti). Desezoniranje je izvršeno US Census Bureau XI2-ARIMA metodom programskom potporom EViews 5.o. Bitno je naglasiti da se radi o nominalnim vrijednostima, kao što je i uobičajeno kod prikazivanja utjecaja fiskalnih šokova na realne varijable. Na prikazima podataka je vidljivo kako proračunski prihodi u znatno većoj mjeri prikazuju sezonske oscilacije dok su one kod rashoda tek minimalne. Unatoč nešto manjim sezonskim oscilacijama, koristit ćemo također desezonirane vrijednosti za proračunske rashode, što je u skladu sa standardnom literaturom.

Prikaz ostalih podataka također je moguće vidjeti u dodatku rada. Potrebno je naglasiti da je indeks industrijske proizvodnje zbog izrazito jakih sezonskih oscilacija također desezonirana istom metodom, dok desezoniranje nije primijenjeno na kamate i inflaciju.

Mjesečni indeks potrošačkih cijena preuzet je iz Hrvatske narodne banke i to kao bazni indeks (baza=2005), a inflacija je izvedena na već opisani način. Kao referentna kamatna stopa korištena je

${ }^{\text {II }}$ Korišteni su podaci prihoda i rashoda državnog proračuna unatoč različitom obuhvatu državnog proračuna u promatranom razdoblju. Konzistentniji podaci bi bili prihodi i rashodi na razini konsolidirane opće države, no zbog nedovoljnog broja opservacija nije ih moguće koristiti u modelu (dostupni kvartalni podaci od 2004). 
kratkoročna kamatna stopa u trgovanju depozitnim novcem među bankama mjerena kao vagana prosječna mjesečna kamata na godišnjoj razini (podaci također preuzeti iz baze podataka Hrvatske narodne banke).

Provedeni su i testovi jediničnog korijena (dodatak 6) te uz $5 \%$ signifikantnosti možemo zaključiti da je jedino kamatna stopa stacionarna u razinama dok ostale varijable sadrže jedinični korijen u razinama, a stacionarne su u prvim diferencijama tj. integrirane su reda jedan. Pri značajnosti od ı\% može se zaključiti da su sve varijable integrirane reda jedan. Bez obzira na činjenicu da varijable sadrže jedinični korijen, u ovoj će se analizi koristiti varijable u razinama, što je uobičajena praksa kod ovakvih istraživanja (Perotti, 2002; de Castro i de Cos, 2006; i Heppke-Falk, Tenhofen i Wolf, 2006), jer nas prvenstveno zanima dinamika, a ne procjena parametara.

\section{Empirijski rezultati}

U dodatku rada moguće je vidjeti funkcije impulsnog odaziva, matrice sa procijenjenim parametrima te dekompoziciju varijance. Svi rezultati dobiveni su programskom potporom EViews 5.o. U dodatku II prikazane su dobivene matrice A i B, dok je u dodatku 12 moguće vidjeti dekompoziciju varijance osnovnog modela.

U dodacima 7 i Io prikazane su sve funkcije impulsnog odaziva za obje korištene metode, tj. za rekurzivnu i strukturalnu metodu. Isprekidane crte označavaju intervale od dvije standardne devijacije, dok pune crte predstavljaju impulsnu funkciju.

Prilikom interpretacije šokova fiskalnih varijabli valja na umu imati činjenicu da šokove državnih izdataka ili državnih prihoda nije uzrokovala niti jedna od ostalih varijabli u modelu, jer su strukturni tj. interpretativni šokovi dobiveni iz reziduala VAR jednadžbi.

Šok izdataka na industrijsku proizvodnju (vidjeti dodatak 7), koji koristimo kao proxy varijablu dohotka, za razliku od dosadašnjih istraživanja efekta fiskalne politike u Hrvatskoj (Rukelj, 2009. i Benazić, 2006), je negativan u kratkom roku. Navedeni utjecaj približava se početnoj vrijednosti nakon dvije godine, a u cjelokupnom razdoblju učinak se nalazi u intervalu od $\pm 0,5$ mjernih jedinica korištene varijable. Jedno od objašnjenja ovog nekonvencionalnog smjera utjecaja može biti prevladavajući efekt istiskivanja privatnih investicija nad efektom dohotka. Dodatni problem predstavlja i nužan izbor industrijske proizvodnje kao jedine, dovoljno duge, mjesečne serije koja služi kao aproksimacija ekonomske aktivnosti. Unatoč neočekivanom rezultatu slične zaključke nalazimo i u Heppke-Falk, Tenhofen i Wolf (2006) te Lozano i Rodrigez (2008). U de Castro i de Cos (2006) pozitivan kratkoročan prerasta u negativan dugoročni efekt.

Šok prihoda na industrijsku proizvodnju nakon tromjesečnog negativnog efekta pretvara se $u$ pozitivni, ali i volatilni učinak. Nakon Io mjeseci navedeni se učinak stabilizira i ne iščezava, što je vjerojatno povezano sa činjenicom da šok poreza ima permanentan utjecaj na same poreze, jer šok poreza tj. promjena poreznih stopa ima trajan efekt na sumu poreznih prihoda. Takva trajna pozitivna reakcija ekonomske aktivnosti dobivena je i u Falk, Tenhofen i Wolf (2006) te Lozano i Rodrigez 
(2008). U de Castro i de Cos (2006) je također prisutan pozitivan efekt, ali u dugom roku se pretvara u negativan, dok u Štikova (2006) državni prihodi nemaju utjecaja na BDP.

Oba fiskalna šoka imaju minimalan efekt na inflaciju (unutar 0.007 mjernih jedinica korištene varijable) koji nakon jedne godine iščezavaju. Početni dvomjesečni efekt šoka izdataka na inflaciju je pozitivan nakon čega prevladava negativan efekt do osmog mjeseca što je u skladu sa udžbeničkim znanjem o ekonomskoj politici stabilnog tečaja (vidjeti primjerice Gärtner, 2006; Mankiw, 2007. i sl.). Porezni šok podiže inflaciju prvih šest mjeseci, a potom se stabilizira unatoč tome što je prisutan permanentan efekt poreza. Razlog tomu je što se šok nakon godinu dana implementira u inflacijska očekivanja. Kod ostalih istraživanja bazirana na SVAR modelima kratkoročni efekt fiskalnih šokova na inflaciju je volatilan, dok je u dugom roku također zanemariv.

Fiskalni šokovi imaju najveći utjecaj na kamatnu stopu (o.5 mjernih jedinica korištene varijable). Smjerovi su u skladu sa zaključcima udžbeničke literature o ekonomskoj politici stabilnog tečaja (vidjeti primjerice Gärtner, 2006; Mankiw, 2007. i sl.). Kamatna stopa reagira negativno na šok poreza, da bi se nakon godine dana stabilizirala na početnoj razini. Šok rashoda unutar dva mjeseca ruši kamatnu stopu, pa je ponovno diže iznad početne razine gdje se zadržava godinu dana. Ovaj zaključak je u skladu s Falk, Tenhofen i Wolf (2006).

Kao što je već rečeno, porezni šok na poreze ima trajan utjecaj tj. pozitivan utjecaj vidljiv je i nakon nekoliko godina. Učinak šoka rashoda na prihode nakon početne volatilnosti iščezava nakon I2 mjeseci. Ovakav efekt u skladu je s rastućim javnim dugom, jer ukoliko porezi dovoljno ne reagiraju na povećanje državnih izdataka, sredstva je potrebno namiriti zaduživanjem.

Rashodi se brzo stabiliziraju nakon inicijalnog šoka rashoda, iz čega je vidljivo, da za razliku od utjecaja šoka prihoda na prihode, buduće razine državne potrošnje ne ovise o nezavisnim šokovima rashoda. Porezni šok ima pozitivan dugoročni utjecaj na razinu državnih rashoda, što je vrlo intuitivno jer permanentno veći prihodi (šok prihoda na ukupne prihode je trajan) omogućuju veće državne izdatke u budućnosti.

Dekompozicija varijance standardni je alat VAR-a, a prikazuje koliki udio u varijanci budućeg razdoblja neke varijable imaju određeni šokovi, tj. raščlanjuje proporciju varijabilnosti svake varijable na dio varijabilnosti koji je posljedica šoka u samoj varijabli i na dio varijabilnosti koji je posljedica šokova u ostalim varijablama (Bahovec i Erjavec, 2009). U dodatku I2 prikazana je dekompozicija varijanci za osnovni SVAR model za period od jednog mjeseca do dvije godine. Rezultati dekompozicije varijance za varijable rashodi državnog proračuna, industrijska proizvodnja, inflacija i kamatna stopa pokazuju da nakon mjesec dana same varijable objašnjavaju znatno više od 90\% varijance svoje prognostičke pogreške. Varijabla industrijska proizvodnje s čak II,56\% objašnjava varijancu prognostičke pogreške varijable prihoda državnog proračuna nakon mjesec dana, što potvrđuje ovisnost prihoda o ekonomskoj aktivnosti. Kod svih varijabli udio objašnjavanja varijance prognostičke pogreške samom sobom brzo opada, što je posebno naglašeno kod varijable rashodi 
državnog proračuna. Isti zaključak vidljiv je i iz funkcije impulsnog odaziva gdje šok rashoda na rashode vrlo brzo iščezava, za razliku od ostalih prikazanih funkcija.

U dodatku Io prikazane su funkcije impulsnog odaziva dobivene faktorizacijom Choleskog. Većina funkcija impulsnog odaziva slična je funkcijama dobivenim SVAR metodologijom, uz određene iznimke. Primjerice, utjecaj šoka prihoda državnog proračuna na inflaciju dobiven faktorizacijom Choleskog pokazuje veću varijabilnost i ima drugačiji kratkoročan učinak. U SVAR modelu trenutno dolazi do povećanja inflacije, dok je u rekurzivnom modelu navedeni efekt vidljiv kasnije. Također, razlika u kratkoročnim efektima između SVAR metodologije i rekurzivnog pristupa vidljiva je i u utjecajima šoka rashoda na prihode te prihoda na rashode.

\section{Provjera stabilnosti modela}

Prvi uvjet stabilnosti, koji pokazuje da se svi parametri karakterističnog polinoma nalaze unutar jediničnog kruga, je zadovoljen, pa je definirani VAR model stabilan. ${ }^{\text {I2 }}$

Dodatan test valjanosti je usporedba SVAR modela sa rekurzivnim modelom, u kojem se koristi dekompoziciju Choleskog. Poredak varijabli je već ranije naveden, a broj pomaka ponovo iznosi pet (prema Akaike informacijskom kriteriju i LM testu). Prikazi funkcija impulsnog odaziva za rekurzivni pristup moguće je vidjeti u dodatku io, a opisani su već ranije.

Uobičajena provjera stabilnosti SVAR modela učinjena je i podjelom serije na dva dijela. Prvi dio obuhvaća razdoblje od oI/200I. do 06/2005. godine, a drugi dio od 07/2005. do 12/2009. godine. Prikazi funkcija impulsnog odaziva za navedene serije dani su dodacima 8 i 9. Korištena je ista metoda identifikacije kao i za cijelu seriju, a broj pomaka je prilagođen informacijskim kriterijima. Za drugu seriju na temelju oba referentna pokazatelja (LM i Akaike informacijski kriterij) dobivaju se tri pomaka. Kod prve serije LM kriterij predlaže tri pomaka, a Akaike informacijski kriterij predlaže pet. Pošto se radi o relativno kratkoj seriji, ali i zbog odabira pomaka u drugoj seriji, odlučili smo se također za tri pomaka. Osim toga, test o isključenim pomacima pokazuje da je četvrti pomak nesignifikantan što dodatno potvrđuje odabir.

Svrha podjele serije na dva dijela je ispitivanje sličnosti funkcija među reakcijama varijabli na šokove u oba promatrana razdoblja. Iz prikaza funkcija je najveća razlika vidljiva kod reakcija industrijske proizvodnje na šok izdataka. U prvom razdoblju je prisutan blago pozitivan efekt, dok je on u drugom dijelu, jednako kao i za ukupan period, negativan. Navedeni rezultat može biti posljedica nekoliko faktora. Postoji mogućnost utjecaja strukturnih promjena $\mathrm{u}$ promatranom razdoblju koji mogu dovesti do promjene $u$ rezultatima. Jedan od razloga može biti pogrešan odabir određene varijable, $t \mathrm{j}$. u ovom slučaju industrijske proizvodnje, ali i pogrešna specifikacija modela dolazi u obzir. Potonje je moguće, ali činjenica da je kod svih ostalih varijabli jasno vidljiva konzistentnost reakcija na fiskalne šokove nas navodi na suprotan zaključak.

${ }^{12}$ Grafički prikaz dan je u dodatku I3. 
Osim navedene podjele učinjeno je još nekoliko testova kako bi se ispitala stabilnost modela, a time i vjerodostojnost dobivenih rezultata. Testovi se odnose na odabir varijabli koje nisu dobivene računskim putem. Najprije je ispitana osjetljivost modela na koeficijent $\alpha_{\pi}^{g}$ odnosno elastičnost državnih izdataka u odnosu na inflaciju. Ranije je objašnjeno zašto je odabrana vrijednost -0.5 prema Perotti (2002), ali je također rečeno kako bi se navedena vrijednost trebala nalaziti između -I i o. Ispitana su oba krajnja slučaja, a rezultati ostaju gotovo nepromijenjeni. Preostali parametar koji nije dobiven računskim putem, niti je odabran zbog posebnih pretpostavki, je parametar $\beta_{F}^{\sharp}$. Pretpostavljeno je da taj parametar iznosi o, što znači da odluke o državnoj potrošnji diktiraju odluke o državnim prihodima. Alternativa ovoj opciji je da će $\beta_{\mathrm{F}}^{g}$ biti procijenjen na uobičajen način, a da

iznosi nula, odnosno vrijedit će pretpostavka da odluke o državnim prihodima diktiraju državnu potrošnju. Kao i u prethodnom slučaju, rezultati se ne mijenjaju što dodatno potvrđuje odabir modela.

\section{Zaključak}

U radu je primijenjena Blanchard-Perotti identifikacijska metoda strukturalne vektorske autoregresije $\mathrm{u}$ analizi makroekonomskih efekata dezagregiranih fiskalnih šokova $\mathrm{u}$ Hrvatskoj. Za razliku od uobičajene kvartalne frekvencije korištena je mjesečna koja također omogućuje primjenu teoretskih pretpostavki potrebnih za točnu identifikaciju modela. Osim nultih restrikcija, $\mathrm{u}$ tu su svrhu procijenjene egzogene elastičnosti gospodarske aktivnosti i inflacije u odnosu na državne prihode. Navedeni postupci omogućili su da se iz reziduala reduciranog oblika VAR modela dobiju strukturne inovacije te pripadajuće ekonomski interpretativne funkcije impulsnog odaziva. Prikladnost specifikacije modela potvrđena je usporedbom s rekurzivnim VAR modelom te dijeljenjem serije na dva jednaka dijela. Ispitana je i osjetljivost modela na arbitrarno odabrani koeficijent utjecaja inovacija inflacije na državnu potrošnju koji također potvrđuje prikladnost specifikacije.

Iz impulsnih funkcija dolazimo do nekoliko osnovnih zaključaka: (I) Relativno najviše reagira kamatna stopa na fiskalne šokove, dok stopa inflacije pokazuje najslabiju reakciju (2) Utjecaj šoka prihoda na prihode je trajan, a utjecaj šoka rashoda na rashode je trenutan, iz čega se izvlače intuitivni zaključci o unakrsnim utjecajima rashoda na prihode i obratno, koje i potvrđuju dobivene impulsne funkcije. (3) Učinak šoka rashoda na prihode je samo kratkotrajan što je u skladu s rastućim javnim dugom, jer ukoliko porezi dovoljno ne reagiraju na povećanje državnih izdataka, sredstva je potrebno namiriti zaduživanjem. (4) Utjecaji fiskalnih šokova na inflaciju i kamatne stope su pretežno ekonomski intuitivni. Porezni šok u kratkom roku povećava stopu inflacije te ujedno smanjuje kratkoročnu kamatnu stopu, a nakon godinu dana dolazi do stabilizacije na početnoj razini. Šok izdataka početno ruši inflaciju, nakon čega je ponovo podiže iznad početne razine, dok na kamatu djeluje u obrnutom smjeru. Izneseni zaključci mogu se objasniti ekonomskom teorijom isključivo ukoliko se pretpostavi da je i reakcija dohotka intuitivna, no kako učinci na industrijsku proizvodnju nisu uobičajeni (porezni šok dovodi do povećanja industrijske proizvodnje, dok ju šok izdataka smanjuje), može se pretpostaviti 
da industrijska proizvodnja nije dobra proxy varijabla dohotka. Pretpostavka o pogrešnom odabiru proxy varijable ne mora biti jedini razlog neočekivanim rezultatima, jer i radovi koji ne koriste proxy varijable, već direktno koriste BDP dolaze do istih neintuitivnih rezultata. (5) Fiskalna ekspanzija ili kontrakcija ukoliko se provodi različitim instrumentima fiskalne politike u istom obujmu ne daje iste rezultate, tj. smanjenje poreza i povećanje državne potrošnje, i obratno, nemaju zrcalni efekt $u$ dobivenim impulsnim funkcijama.

Smatramo da je najveći doprinos ovog istraživanja u ispitivanju posljedica fiskalne politike na inflaciju i kamatnu stopu te odvojeno promatranje učinaka instrumenata fiskalne politike, kao i ispitivanje njihovog međusobnog utjecaja.

Primijenjena metodologija i zaključci mogu poslužiti kao benchmark za usporedbu sa rezultatima budućih istraživanja o posljedicama fiskalne politike u kojima bi se koristile druge metode kao što je fisklani dummy pristup, Bayesian strukturni VAR model ili čak teoretski dinamički stohastički model opće ravnoteže. Također postoji mogućnost izmjene i dodavanja pojedinih varijabli, kao što je npr. uključivanje varijabli o tržištu rada u SVAR. Osim toga ostaje otvoreno pitanje korištenja adekvatne proxy varijable za ekonomsku aktivnost. Jedno od mogućih rješenja je sastavljanje složenijeg kompozitnog indeksa ekonomske aktivnosti koji osim industrijske proizvodnje uključuje i razne druge varijable kako bi se što kvalitetnije aproksimiralo kretanje ukupne ekonomske aktivnosti. Tek kada bude dostupna dovoljno duga serija podataka o nacionalnim računima koja bi omogućila kvalitetnu ekonometrijsku analizu bit će moguće ispitati posljedice fiskalnih šokova na BDP kao i na komponente BDP-a odnosno osobnu potrošnju i agregatne investicije. 


\section{Dodatak}

Dodatak I.

Originalne $i$ desezonirane vrijednosti prihoda državnog proračuna izražene u logaritmima

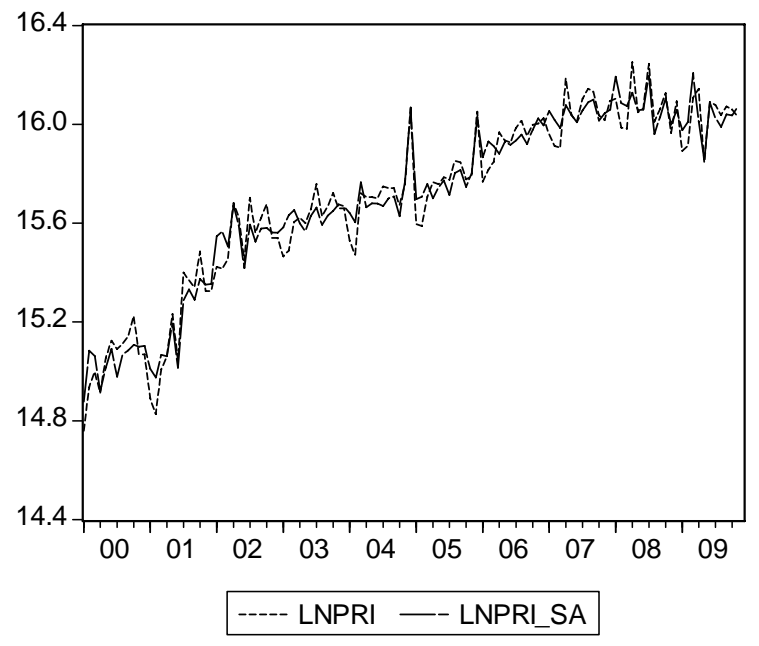

Izvor: Mjesečnici Ministarstva financija RH.

\section{Dodatak 3.}

Originalan i desezoniran bazni indeks (baza=2005) industrijske proizvodnje izražen u logaritmima

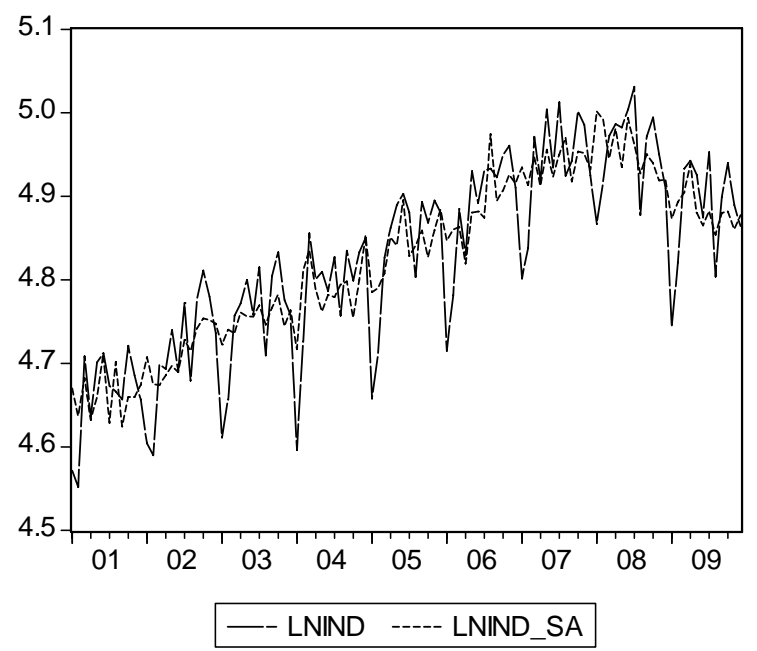

Izvor: Državni zavod za statistiku.
Dodatak 2.

Originalne $i$ desezonirane vrijednosti rashoda državnog proračuna izražene u logaritmima

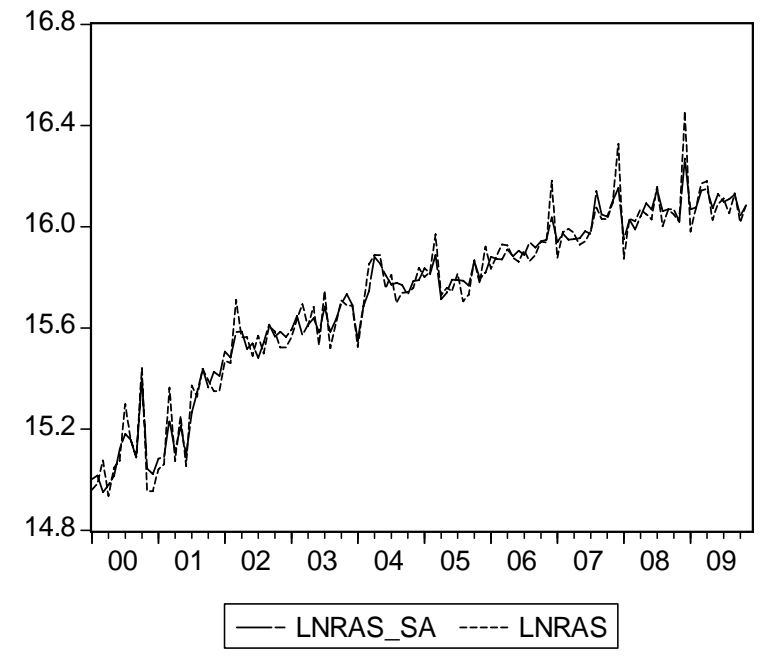

Izvor: Mjesečnici Ministarstva financija $\mathrm{RH}$.

\section{Dodatak 4.}

Mjesečna inflacija (diferencija logaritmirane vrijednosti indeksa potrošačkih cijena)

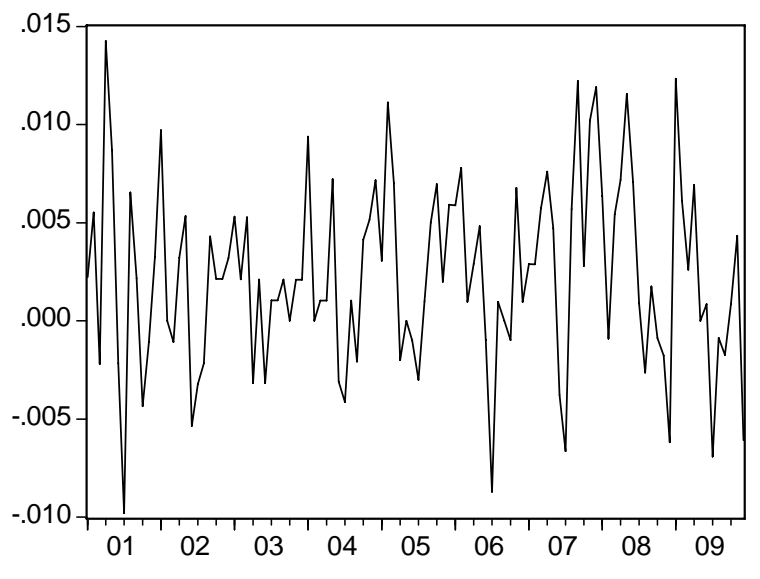

Izvor: Hrvatska narodna banka. 


\section{Dodatak 5.}

\section{Kratkoročna kamatna stopa u}

trgovanju depozitnim novcem među bankama

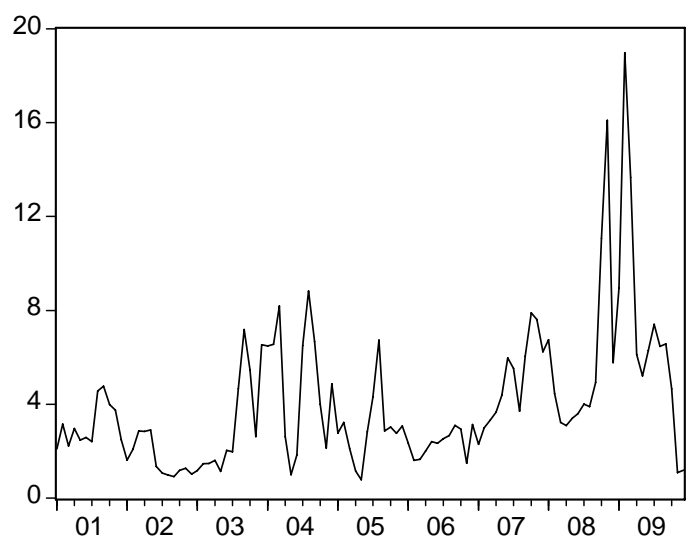

Izvor: Hrvatska narodna banka.

Dodatak 6.

Rezultati proširenog Dickey-Fulerovog testa

\begin{tabular}{|l|c|c|c|c|c|c|}
\hline \multirow{2}{*}{ VARIJABLE } & \multicolumn{3}{|c|}{ Razina } & \multicolumn{3}{c|}{ Diferencija } \\
\cline { 2 - 7 } & bez & konst. & trend+konst. & bez & konst. & trend+konst. \\
\hline LNCPI & 3,95 & $-\mathrm{O}, 8 \mathrm{O}$ & $-2,27$ & $-7, \mathrm{I} 4^{*}$ & $-8,54^{*}$ & $-8,52^{*}$ \\
\hline LNIND_SA & $\mathrm{I}, 97$ & $-2, \mathrm{OI}$ & $\mathrm{O}, 367$ & $-\mathrm{I} 2,4 \mathrm{O}^{*}$ & $-\mathrm{I} 2,57^{*}$ & $-8,95^{*}$ \\
\hline LNPRI_SA & 2,28 & $-\mathrm{I}, 26$ & $-\mathrm{I}, 29$ & $-\mathrm{I} 5,87^{*}$ & $-\mathrm{I} 6,33^{*}$ & $-\mathrm{I}^{*}, 34^{*}$ \\
\hline LNRAS_SA & $\mathrm{I}, 7 \mathrm{O}$ & $-\mathrm{I}, \mathrm{II}$ & $-2,75$ & $-\mathrm{I} 9,33^{*}$ & $-\mathrm{II}, \mathrm{OI}^{*}$ & $-\mathrm{IO}_{9} 8^{*}$ \\
\hline KTA & $-2, \mathrm{OI}^{* *}$ & $-3, \mathrm{O} 6^{* *}$ & $-3,2 \mathrm{I}$ & $-\mathrm{I} 2,88^{*}$ & $-\mathrm{I} 2,85^{*}$ & $-\mathrm{I}^{*}, 8 \mathrm{O}^{*}$ \\
\hline
\end{tabular}

Napomena: Optimalan broj pomaka prema Schwarzovom informatičkom kriterija (Maxlag = I2), gdje * $i$ ** predstavlja odbacivanje nulte hipoteze pri razinama signifikantnosti od I\% i 5\% za kritične vrijednosti -2,586 i -I,943 bez konstante i trenda, -3,49I $i$-2,888 sa konstantom i bez trenda te -4,048 i-3,453 sa konstantom i trendom. 


\section{Dodatak 7.}

Funkcije impulsnog odaziva fiskalnih šokova od jedne standardne devijacije za SVAR model (pune crte predstavljaju funkcije, isprekidane crte odstupanje od dvije standardne devijacije, na ordinati su razine pojave izražene u mjernim jedinicama varijable, a na apscisi vrijeme izraženo u mjesecima)

Prikaz posljedice šoka rashoda na:

Industrijsku proizvodnju

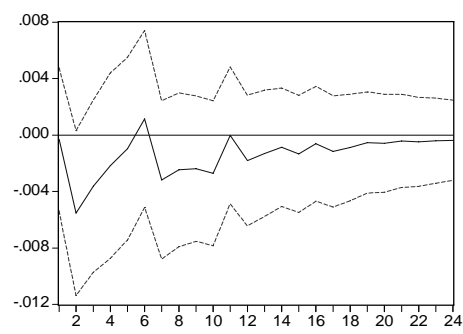

Inflaciju

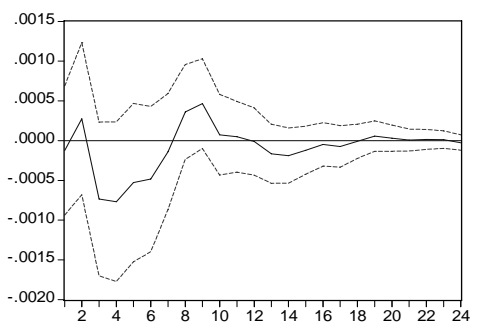

Kamatu

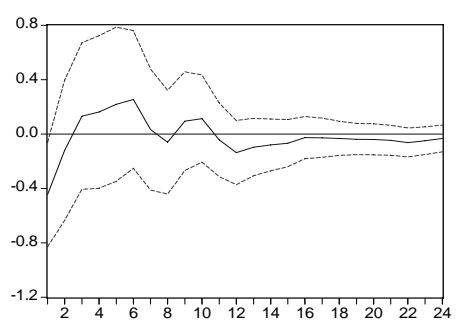

Prihode

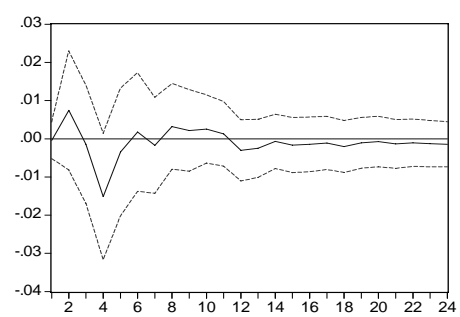

Rashode

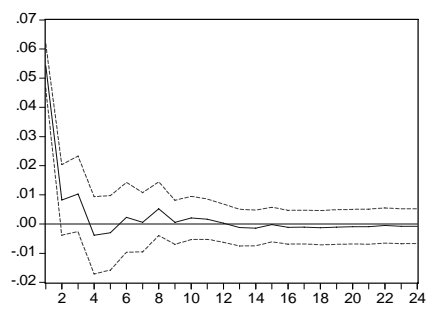

Prikaz posljedice šoka prihoda na:

Industrijsku proizvodnju

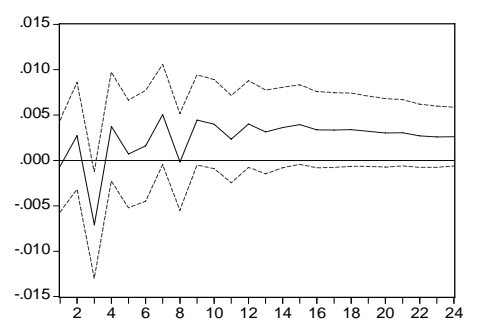

Inflaciju

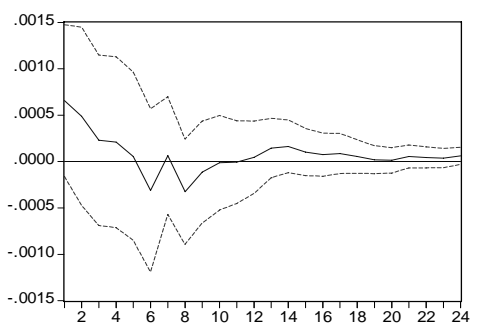

Kamatu

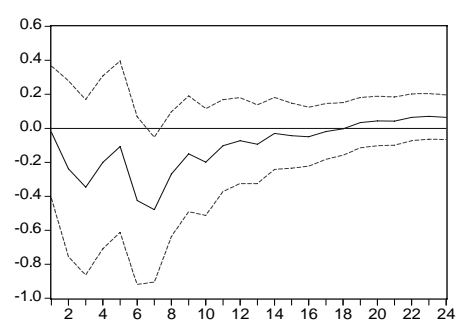

Rashode

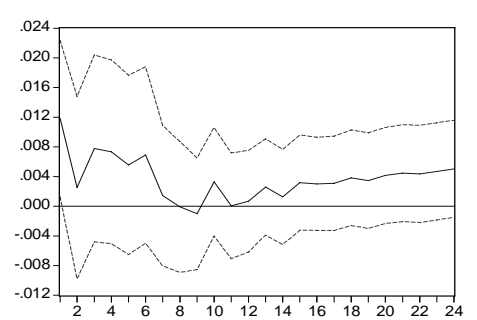

Prihode

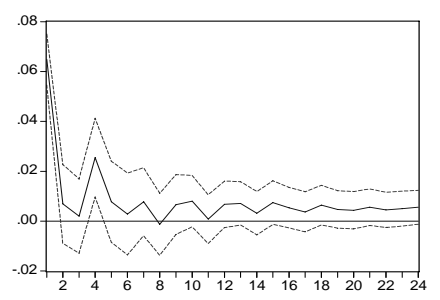


Dodatak 8.

Funkcije impulsnog odaziva za prvu polovicu razdoblja (OI/200I - 06/2005) za SVAR model

Prikaz posljedice šoka rashoda na:

Industrijsku proizvodnju

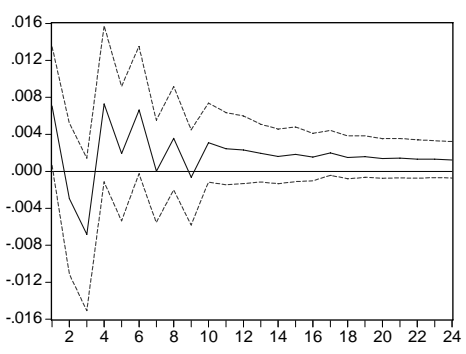

Inflaciju

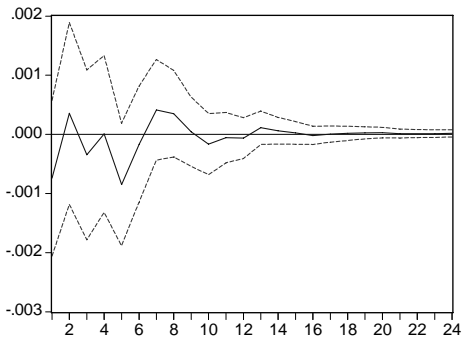

Kamatu

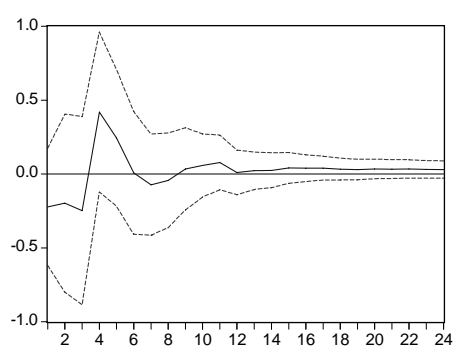

Prihode

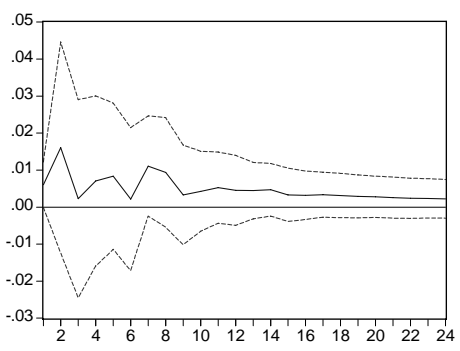

Rashode

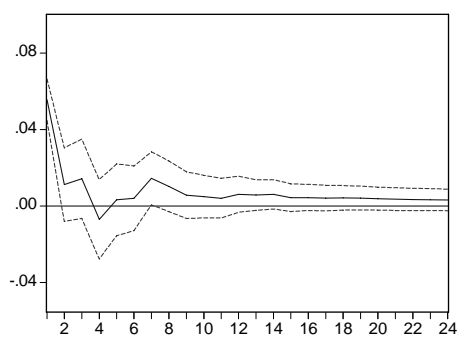

Prikaz posljedice šoka prihoda na: Industrijsku proizvodnju

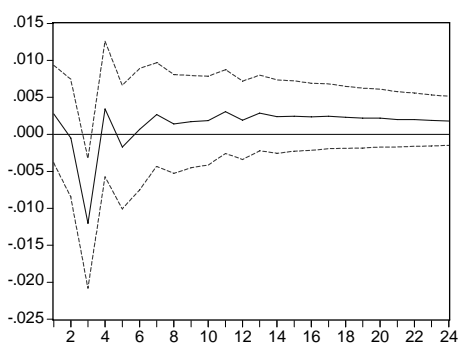

Inflaciju

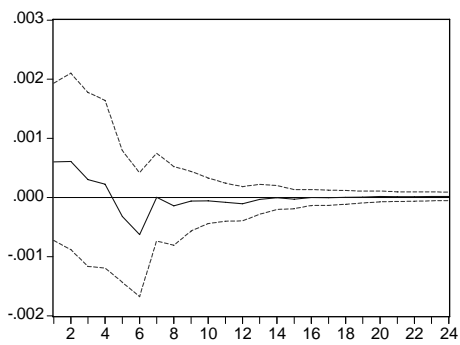

Kamatu

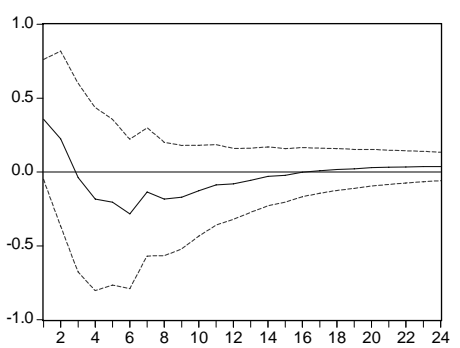

Rashode

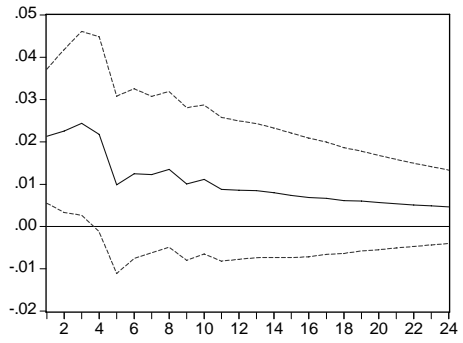

Prihode

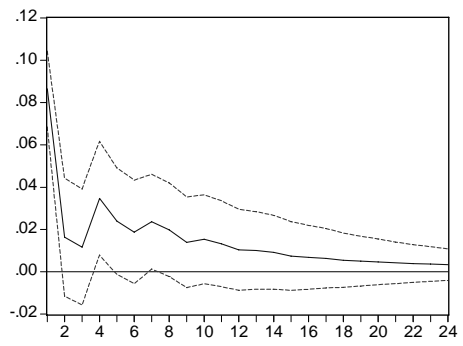




\section{Dodatak 9.}

Funkcije impulsnog odaziva za drugu polovicu razdoblja (07/2005 - I2/2009) za SVAR model

Prikaz posljedice šoka rashoda na:

Industrijsku proizvodnju

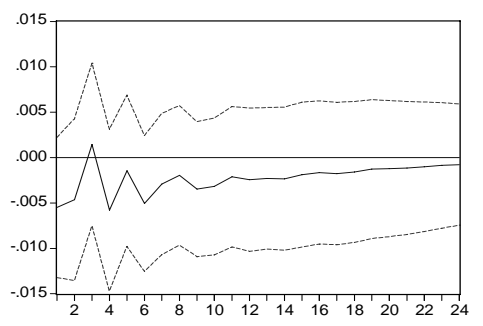

Inflaciju

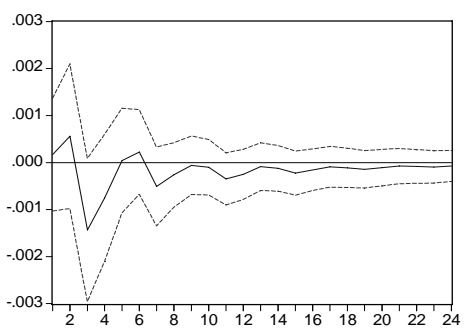

Kamatu

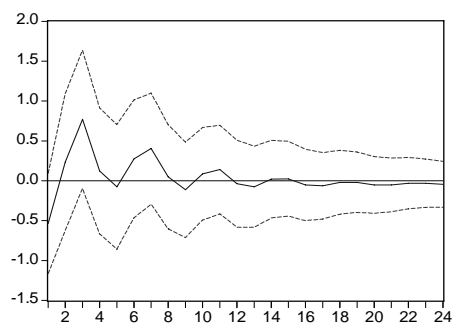

Prihode

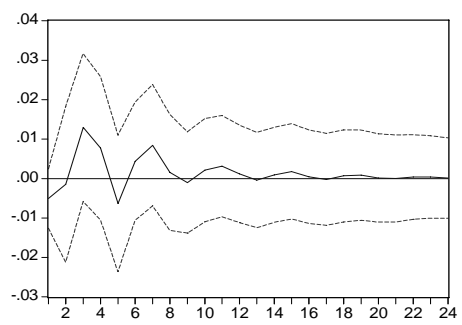

Rashode

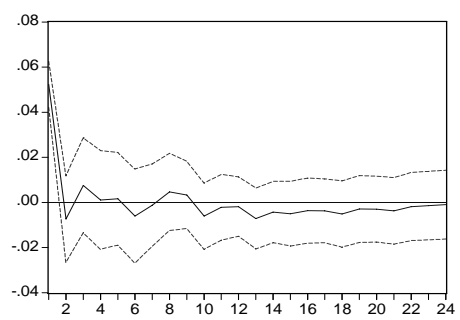

Prikaz posljedice šoka prihoda na:

Industrijsku proizvodnju

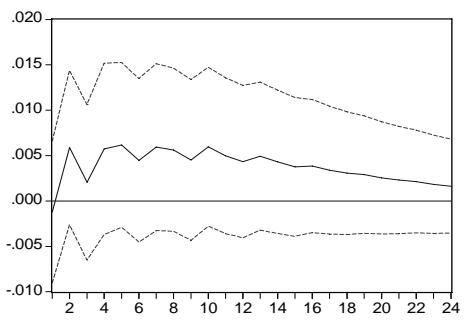

Inflaciju

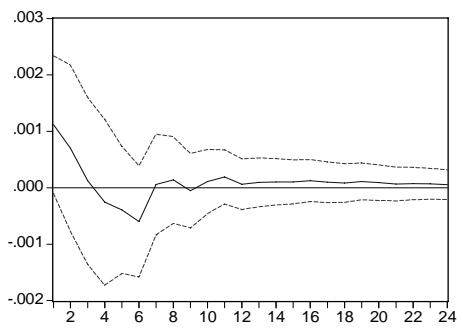

Kamatu

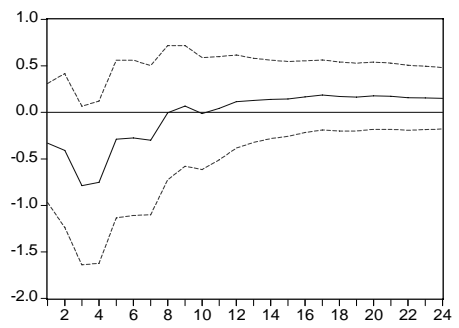

Rashode

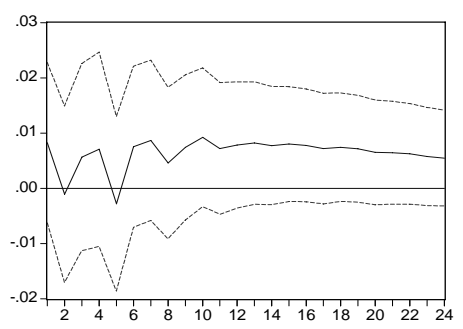

Prihode

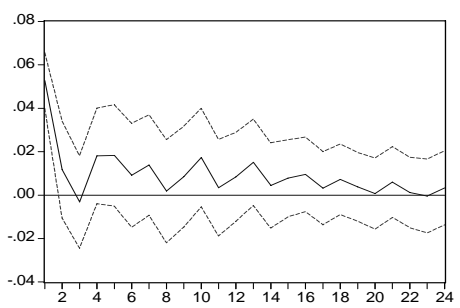




\section{Dodatak Io.}

Funkcije impulsnog odaziva fiskalnih šokova za rekurzivni model

Prikaz posljedice šoka rashoda na:

Industrijsku proizvodnju
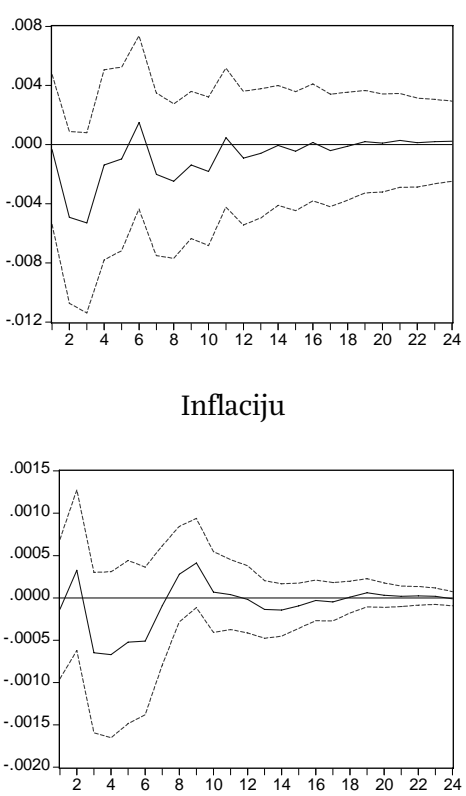

Kamatu

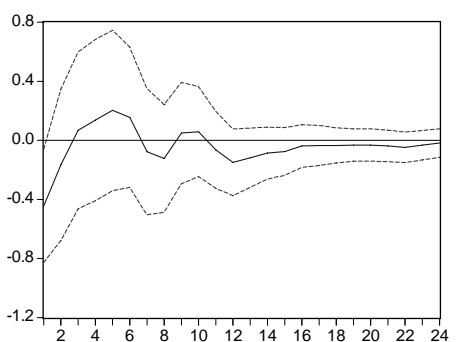

Prihode

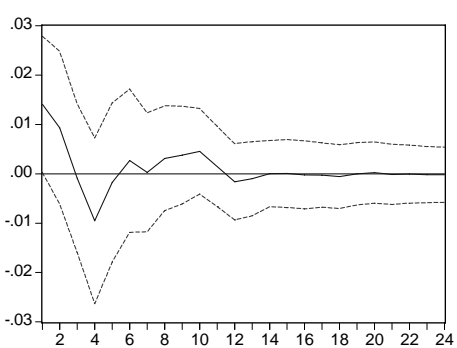

Rashode

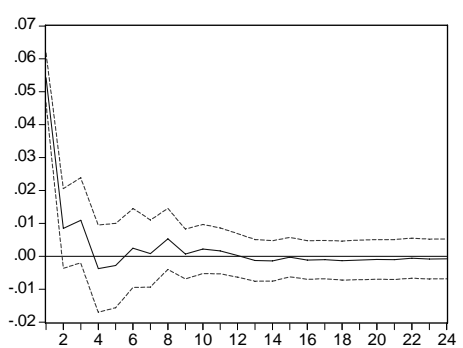

Prikaz posljedice šoka prihoda na: Industrijsku proizvodnju

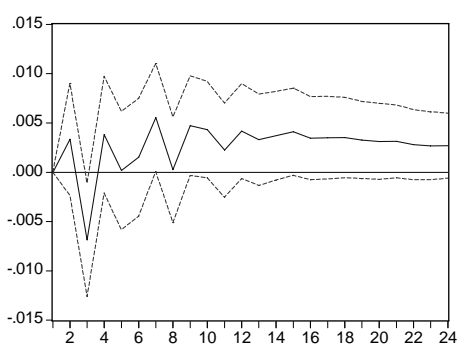

Inflaciju

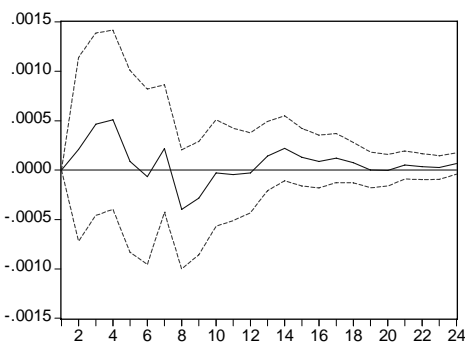

Kamatu

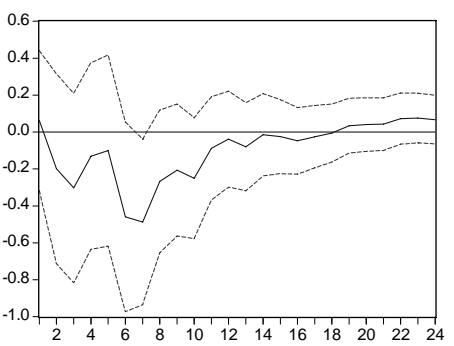

Rashode

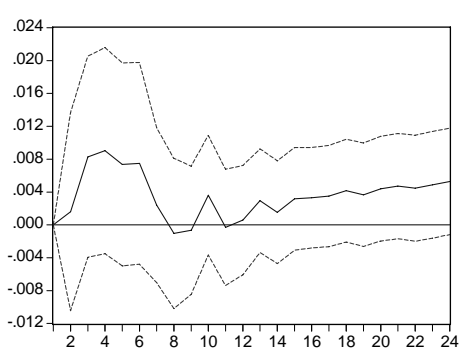

Prihode

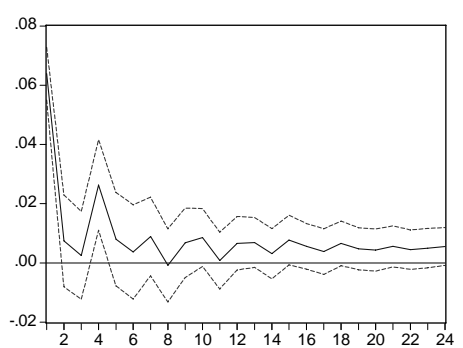


Dodatak II.

Dekompozicija varijance SVAR modela

\begin{tabular}{|c|c|c|c|c|c|c|}
\hline \multicolumn{7}{|l|}{ Rashodi } \\
\hline Period & S.E & $e^{B}$ & $e^{y}$ & $e^{n}$ & $e^{p}$ & $e^{r}$ \\
\hline I mjesec & 0,0542 & 99,85 & O,OOI & O,I42 & 0,003 & 0,000 \\
\hline 6 mjeseci & 0,0679 & $68, \mathrm{I} 4$ & $7,7 \mathrm{OI}$ & 7,997 & 4,049 & I2,II \\
\hline I2 mjeseci & 0,0747 & 56,87 & 19,29 & 7,444 & 3,587 & $\mathrm{I} 2,79$ \\
\hline I8 mjeseci & 0,0805 & 49,09 & 28,58 & $6,62 I$ & 4,053 & II,46 \\
\hline 24 mjeseca & 0,0864 & 42,74 & 33,58 & 5,950 & 5,286 & $\mathrm{I} 2,43$ \\
\hline \multicolumn{7}{|c|}{ Industrijska proizvodnja } \\
\hline Period & S.E & $e^{g}$ & $e^{y}$ & $e^{\pi}$ & $e^{p}$ & $e^{r}$ \\
\hline I mjesec & 0,025 & 0,028 & 99,92 & 0,000 & 0,045 & o,ooo \\
\hline 6 mjeseci & 0,034 & 4,433 & 76,93 & 6,831 & 5,989 & $5,8 \mathrm{II}$ \\
\hline I2 mjeseci & O,O4I & 3,978 & 67,69 & 5,448 & 9,909 & I2,96 \\
\hline I8 mjeseci & 0,045 & 3,406 & 63,74 & 4,694 & $\mathrm{I} 2,24$ & I5,9I \\
\hline 24 mjeseca & 0,047 & 3,172 & $62,2 \mathrm{I}$ & 4,360 & 13,66 & 16,59 \\
\hline \multicolumn{7}{|l|}{ Inflacija } \\
\hline Period & S.E & $e^{g}$ & $e^{y}$ & $e^{\pi}$ & $e^{p}$ & $e^{r}$ \\
\hline I mjesec & 0,004 & 0,004 & $\mathrm{I}, 082$ & 96,36 & 2,549 & 0,000 \\
\hline 6 mjeseci & 0,005 & 6,438 & 5,394 & 79,31 & 3,879 & 4,969 \\
\hline I2 mjeseci & 0,005 & 6,959 & $5,4 \mathrm{I} 4$ & 76,97 & 4,359 & 6,292 \\
\hline I8 mjeseci & 0,005 & 7,045 & 5,446 & 76,29 & 4,692 & 6,518 \\
\hline 24 mjeseca & 0,005 & 7,051 & 5,452 & 76,13 & 4,715 & 6,640 \\
\hline \multicolumn{7}{|l|}{ Prihodi } \\
\hline Period & S.E & $e^{g}$ & $e^{y}$ & $e^{\pi}$ & $\rho^{p}$ & $\boldsymbol{p}^{r}$ \\
\hline I mjesec & 0,070 & 4,213 & $\mathrm{II}, 56$ & 0,264 & 83,95 & 0,000 \\
\hline 6 mjeseci & 0,087 & 5,240 & 18,65 & I,OI7 & 65,18 & 9,900 \\
\hline I2 mjeseci & 0,094 & 4,999 & 25,60 & 1,386 & 57,89 & IO,II \\
\hline I8 mjeseci & 0,099 & 4,520 & 29,72 & 1,327 & 54,21 & IO,2I \\
\hline 24 mjeseca & O,IO3 & 4,183 & 32,33 & 1,262 & 51,52 & IO,69 \\
\hline \multicolumn{7}{|c|}{ Kamatna stopa } \\
\hline Period & S.E & $e^{g}$ & $e^{y}$ & $e^{\pi}$ & $e^{p}$ & $e^{r}$ \\
\hline I mjesec & $\mathrm{I}, 974$ & 4,948 & 0,003 & 0,205 & 0,153 & 94,68 \\
\hline 6 mjeseci & 2,915 & 3,480 & 5,894 & 8,477 & 5,684 & 76,46 \\
\hline I2 mjeseci & 3,050 & 3,758 & 6,419 & $9,4 \mathrm{I} 5$ & 9,204 & $7 \mathrm{I}, 2 \mathrm{O}$ \\
\hline I8 mjeseci & 3,087 & 3,979 & 7,620 & $9,49 \mathrm{I}$ & 9,068 & 69,84 \\
\hline 24 mjeseca & $3, \mathrm{I} 2 \mathrm{I}$ & 3,959 & 8,475 & 9,460 & 9,II4 & 68,99 \\
\hline
\end{tabular}

Napomena: $\Xi^{g}$ je strukturna inovacija izdataka državnog proračuna, $\theta^{y}$ strukturna inovacija dohotka, $\Xi^{\pi}$ strukturna inovacija inflacije, a $\boldsymbol{e}^{p}$ i $\boldsymbol{e}^{T}$ su strukturne inovacije prihoda državnog proračuna i kamatne stope.

\section{Dodatak 12.}

Procijenjeni koeficijenti matrica A i B Blanchard-Perotti metodom

$$
A=\left[\begin{array}{ccccc}
1 & 0 & 0.5 & 0 & 0 \\
0.0057 & 1 & 0 & 0.0084 & 0 \\
0.0023 & 0.0263 & 1 & -0.0100 & 0 \\
0 & -0.9510 & -0.892 & 1 & 0 \\
8.3782 & 1.0134 & -16.7556 & -0.9701 & 1
\end{array}\right] \quad B=\left[\begin{array}{ccccc}
0.0542 & 0 & 0 & 0 & 0 \\
0 & 0.0259 & 0 & 0 & 0 \\
0 & 0 & 0.0040 & 0 & 0 \\
0.0149 & 0 & 0 & 0.0671 & 0 \\
0 & 0 & 0 & 0 & 1.921
\end{array}\right]
$$


Dodatak I3.

Prikaz jediničnog kruga i parametara karakterističnog polinoma

Reducirani oblik VAR modela

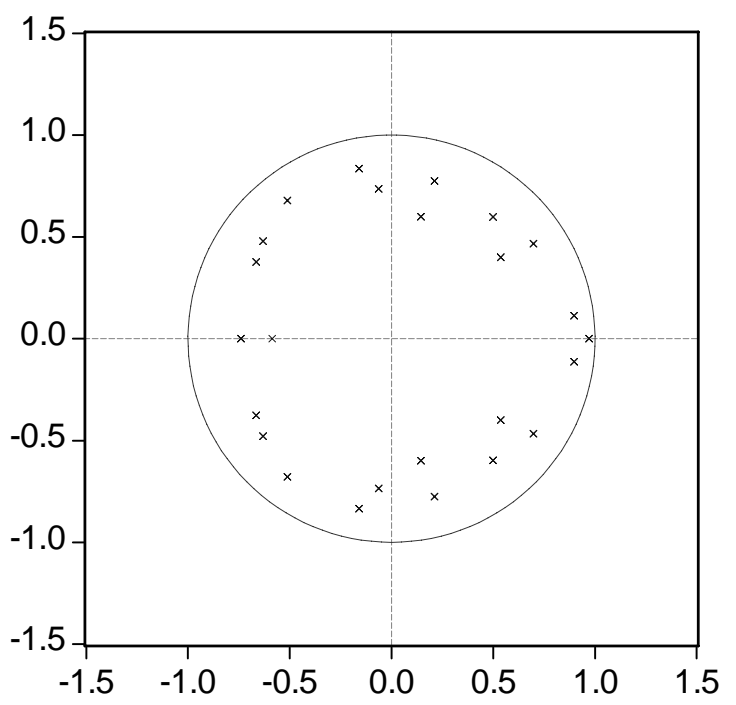

Reducirani oblik VAR modela za razdoblje 200I/OI -

Reducirani oblik VAR modela za razdoblje 2005/07 2005/o6 2009/12
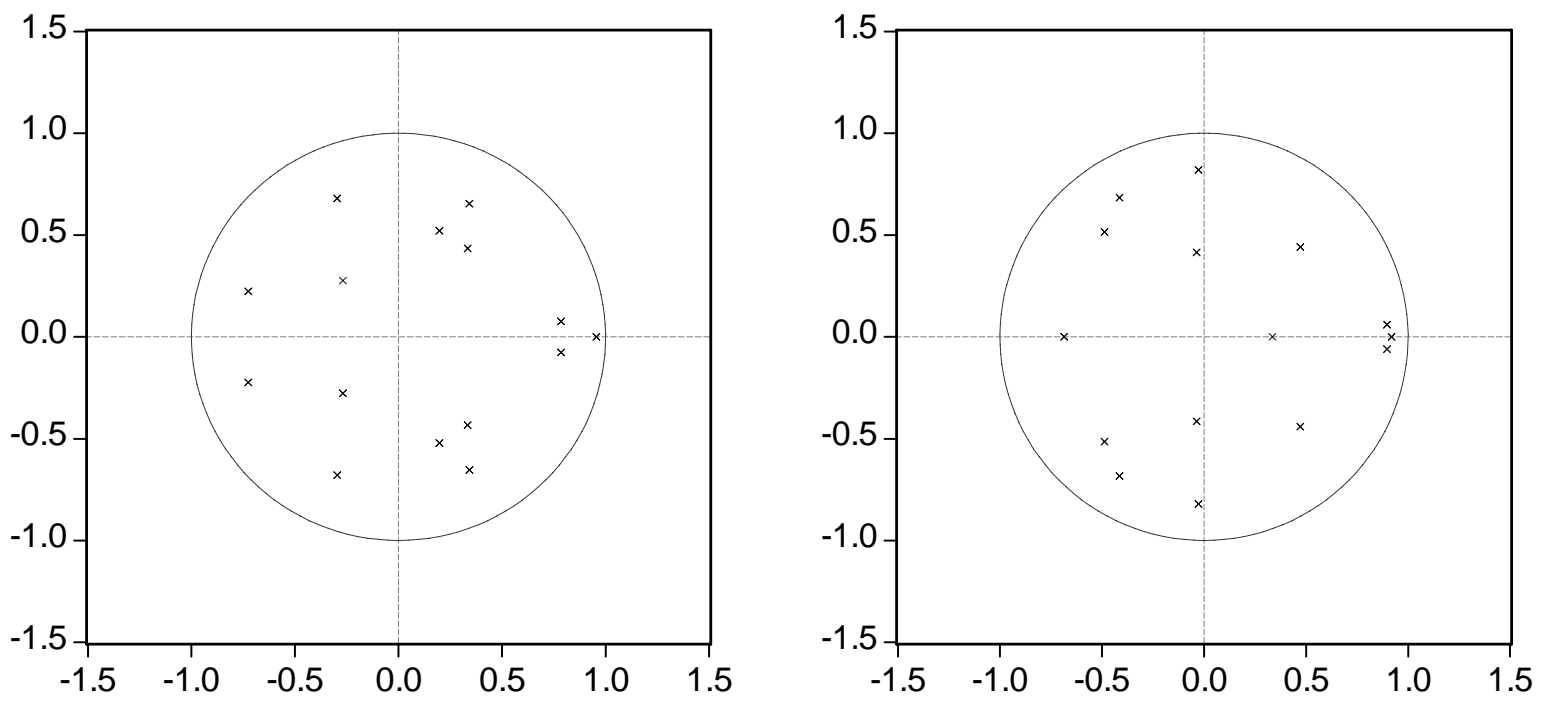


\section{Literatura}

Afonso, A. and Sousa, R. M., 2009a. "The Macroeconomic Effect of Fiscal Policy in Portugal: A Bayesian SVAR Analysis." Technical University of Lisbon, School of Economics and Management Working Paper series o9/2009 [online]. Available from: [http://www3.eeg.uminho.pt/economia/nipe/docs/2009/NIPE_WP_3_2009.pdf].

Afonso, A. and Sousa, R. M., 2009b. "The Macroeconomic Effects of Fiscal Policy" [online]. ECB Working Paper, No 991. Available from: [https://www.repository.utl.pt/bitstream/I0400.5/2156/I/ecbwp99I.pdf].

Bahovec, V. and Erjavec, N., 2009. Uvod u ekonometrijsku analizu. Zagreb: Element.

Benazić, M., 2006. "Fiskalna politika i gospodarska aktivnost u Republici Hrvatskoj: model kointegracije." Ekonomski pregled, 57 (I2) 882-918.

Bernanke, B. S. and Mihov, I., 1997. "What Does the Bundesbank Target?" European Economic Review, I4 (6), IO25-IO53.

Blanchard, O. J. and Perotti, R., 1999. "An Empirical Characterization of the Dynamic Effects of Changes in Government Spending and Taxes on Output” [online]. NBER Working Paper Series, No. 7269. Available from: [http://www.nber.org/papers/w7269.pdf].

CBS. Monthly Statistical Report, No. I/O6, I2/o6, OI/O7, I2/O7, OI/o8, I2/08, OI/O9, I2/o9, oI/IO. Zagreb: Croatian Bureau of Statistics.

CNB, 20Io. CNB database [online]. Available from: [www.hnb.hr/statistika/hstatistka.htm].

de Arcangelis, G. and Lamartina, S., 2003. "Identifying Fiscal Shocks and Policy Regimes in OECD Countries" [online]. ECB Working Paper, No. 28I. Available from: [http://www.ecb.europa.eu/pub/pdf/scpwps/ecbwp28I.pdf].

de Castro, F. and de Cos, P. H., 2006. "The Economic Effects of Exogenous Fiscal Schocks in Spain: A SVAR Approach“ [online]. Banco de Espana, Documentos de Trabajo, No 06IO4/2006. Available from: [http://www.ecb.europa.eu/pub/pdf/scpwps/ecbwp28I.pdf].

de Plesis, S., Smit, B. and Struzenegger, F., 2007. "The Cyclicality of Monetary and Fiscal Policy in South Africa Since 1994" [online]. University of Stellenbosch Economic Working Papers, No. 12/07. Available hrom: [:www.ekon.sun.ac.za/wpapers/2007/wpi22007/wp-I2-2007.pdf].

Enders, W., 2003. Applied Econometric Time Series. New Yorf: John Wiley \& Sons, Inc.

Fatas, A. and Mihov, I., 20oIa. "Fiscal Policy and Business Cycles: An Empirical Investigation." Moneda y Credito, 2I2, I67-210.

Fatas, A. and Mihov, I., 20orb. "The Effects of Fiscal Policy on Consumption and Employment: Theory and Evidence" [online]. CEPR Discussion Paper, No. 2760. Available from: [http://faculty.insead.edu/fatas/fiscal.pdf].

Favero, C., 2002. "How do Monetary and Fiscal Authorities Behave?" [online]. CEPR Discussion paper, No 3426. Available from: [ftp://ftp.igier.uni-bocconi.it/wp/2002/2I4.pdf].

Galí, J., López-Salidoz, J. D. and Vallés, J., 2007. "Understanding the Effects of Government Spending on Consumption.” Journal of the European Economic Association, 5 (I), 227-270.

Gärtner, M., 2006. Macroeconomics. London: Prentica Hall.

Giordano, R. [et al.], 2008. "The Effects of Fiscal Policy in Italy: Estimates with a SVAR model." Presented at: Banca d'Italia, 7 th Workshop on Public Finance.

Gottschalk J., 20oI. "An Introduction into the SVAR methodology: Identification, Interpretation and Limitations of SVAR models" [online]. Kiel Working Paper, No. IO72. Available from: [www.econstor.eu/bitstream/IO419/17887/I/kapio72.pdf].

Heppke-Falk, K. H., Tenhofen, J. and Wolf, G. B., 2006. "The Macroeconomic Effects of Exogenous Fiscal Policy Shocks in Germany: a Disaggregated SVAR Analysis" [online]. Deutsche Bundesbank Discussion Paper Series I: Economic Studies, No 4I/2006. Available from: [http://econstor.eu/bitstream/I04I9/19670/I/20064Idkp.pdf].

Kamps, C. and Caldara, D., 2008. "What are the Effects of Fiscal Policy Shocks? A VAR-based Comparative Analysis" [online]. ECB Working Paper, No 877. Available from: [http://www.ecb.europa.eu/pub/pdf/scpwps/ecbwp877.pdf]. 
Kamps, C., Caldara, D., 2006. "What Do we Know about the Effects of Fiscal Policy Shocks? A Comparative Analysis." Computing in Economics and Finance Series, No. 257/2006. [online]. Available at: http://repec.org/sce2006/up.9905.II40994990.pdf

Keating, J. W., 1992. Structural Approaches to Vector Autoregressions. Washington: Federal Reserve Bank of St. Louis

Krušec., D 2003. "The effects of fiscal policy on output in a structural VEC model framework: The case of four EMU and four non-EMU OECD countries." Presented at: University of Crete 8th International Conference of Macroeconomics Analysis and International Finance, 03/2004.

Lozano, I. and Rodriquez, K., 2008. "Assessing the Macroeconomic Effects of Fiscal Policy in Colombia” [online]. Banco de la Republica, Borradores de Economia Working Paper, No. 552/2009. Available from: [www.bcu.gub.uy/autoriza/peiees/jor/2009/ieeso3j30IIoog.pdf].

Lütkepohl, H., 2005. New Introduction to Multiple Time Series Analysis. Berlin; Heidelberg; New York: Springer.

Mankiw, G. N., 2007. Macroeconomics. New York: Worth Publishers.

McCoy, D., 1997. How useful is Structural VAR Analysis for Irish Economics. Dublin: Economic Analysis, Research and Publications Department, Central Bank of Ireland.

Ministry of Finanace. Monthly Statistical Report of the Ministry of Finance, No. 63, 74, 75, 86, 96, 99, IIO, III, I22, I23, I35, I36, I47, I 48 [online]. Available from: [www.mfin.hr/mjesečni-statistički-prikazi].

Mountford, A. and Uhlig, H., 2005. "What Are the Effects of Fiscal Policy Shocks?" SFB 649 Discussion Paper 2005-039. Berlin: Humboldt University.

Perotti, R., 2002. "Estimating the Effects of Fiscal Policy in OECD Countries" [online]. ECB Working Paper, No. 168. Available from: [http://www.ecb.int/pub/pdf/scpwps/ecbwpi68.pdf].

Ramey, V., A. and Shapiro., M. D., 1998. "Costly Capital Reallocation and the Effects of Government Spending” [online]. Carnegie-Rochester Conference Series on Public Policy, 48 (June), I45-I94. Available from: $\quad$ http://www.sciencedirect.com/science/article/B6V8D-3VNGGBF7/2/439aogi8c6fioff2fio7fi6e2036b6eb].

Rukelj, D., 2009. "Modelling Fiscal and Monetary Policy Interactions in Croatia Using Structural Vector Error Correction Model.” Privredna kretanja i ekonomska politika, I2I, 27-58.

Sopek, P., 2009. "The Effect of the Financial Crisis on Croatia's Primary Budget Deficit and Public Debt" [online]. Financial Theory and Practice, 33 (3), 273-298. Available from: [http://www.ijf.hr/eng/FTP/2009/3/sopek.pdf].

Štiková, R., 2006. Effects of Fiscal Policy in the Czech Republic: a SVAR analysis [online]. Available from: [ies.fsv.cuni.cz/default/file/download/id/555I].

Švaljek, S., Vizek, M. and Mervar, A., 2009. "Ciklički prilagođeni proračunski saldo: Primjer Hrvatske." Privredna kretanja i ekonomska politika, I2O, 49-8I. 